\title{
Thermal History and Potential of Hydrocarbon Generated from Jurassic to Early Cretaceous Source Rocks in the Malita Graben, Northern Bonaparte Basin, Australia
}

\author{
Rakotondravoavy Jules",2*, Ye Jia Ren1, Cao Qiang1 \\ ${ }^{1}$ Key Laboratory of Tectonics and Petroleum Resources, China University of Geosciences, MOE, Wuhan, China \\ ${ }^{2}$ Department of Earth Science and Environment, Faculty of Science, University of Mahajanga, Mahajanga, \\ Madagascar \\ Email: ${ }^{*}$ rakoto@mail.ru
}

Received 23 June 2015; accepted 28 August 2015; published 31 August 2015

Copyright (C) 2015 by authors and Scientific Research Publishing Inc.

This work is licensed under the Creative Commons Attribution International License (CC BY).

http://creativecommons.org/licenses/by/4.0/

(c) $\underset{\mathrm{EY}}{\mathrm{i}}$ Open Access

\section{Abstract}

The Malita Graben is located in the northern Bonaparte Basin, between the Sahul Platform to the northwest and the Petrel Sub-basin and Darwin Shelf to the south. The wells Beluga 1, Heron 1, Evans Shoal 1, Evans Shoal 2 and Seismic Line N11805 are selected to determine the thermal history and potential of hydrocarbon generated from the Plover, Elang, Frigate Shale (Cleia and Flamingo), and Echuca Shoals formations source rocks. The modeling was performed by using Basin Mod 1-D and 2-D techniques. The model results show that the geothermal gradients range from 3.05 to $4.05^{\circ} \mathrm{C} / 100 \mathrm{~m}$ with an average of $3.75^{\circ} \mathrm{C} / 100 \mathrm{~m}$ and present day heat flow values from 46.23 to $61.99 \mathrm{~mW} / \mathrm{m}^{2}$ with an average of $56.29 \mathrm{~mW} / \mathrm{m}^{2}$. The highest geothermal gradient and present-day heat flow values occurred on a terrace north of the Malita Graben. These most likely indicate that hot fluids are currently variably migrating into this structure. The lower geothermal gradient and heat flow values have been modeled in the southeast sites in the well Beluga 1 . The northern Bonaparte Basin experienced several deformation phases including lithospheric thinning; hence, heat flow is expected to vary over the geological history of the basin. The higher paleo-heat flow values changing from 83.54 to $112.01 \mathrm{~mW} / \mathrm{m}^{2}$ with an average of $101.71 \mathrm{~mW} / \mathrm{m}^{2}$ during Jurassic rift event (syn-rift) were sufficient for source rocks maturation and hydrocarbon generation during Cretaceous post-breakup sequence (post-rift) in the study area. The Tuatara (Upper Frigate Shale) Formation source rock with type II \& III kerogen dominantly showing mixed oil- and gas-prone, and Plover Formation with type III and gas prone have never reached the peak

\footnotetext{
*Corresponding author.
} 
mature oil window in the well Beluga 1 . This area indicates that the maturity of source rocks is low and considered to be from poor-to-good organic richness with poor-to-fair potential for hydrocarbons generation. The post mature Cleia (Lower Frigate Shale) and Echuca Shoals formations source rocks in the well Evans Shoal 1 and an early mature oil window Echuca Shoals formation source rock in the well Evans Shoal 2, characterized by type III kerogen dominantly showing gasprone are a fair-to-very good source richness with poor potential for hydrocarbons generation. The low to high maturity of Echuca Shoals and Petrel (Frigate Shale) formations source rocks in the well Heron 1, Plover Formation source rock in the Evans Shoal 1 well, and Cleia (Lower Frigate Shale) and Plover formations in the well Evans Shoal 2, showing gas-prone with type III and II \& III kerogens predominantly, have reached the late mature oil and wet gas generation stages at present day. These last five formations source rocks are seen from poor-to-very good organic richness with poor-to-very good potential for hydrocarbons generation in the Malita Graben.

\section{Keywords}

\section{Malita Graben, Northern Bonaparte Basin, Potential Generating Hydrocarbon, Thermal History}

\section{Introduction}

The Malita Graben is a northeast-trending dominantly Mesozoic-Cenozoic depocentre (Triassic) in the northern Bonaparte Basin that lies between the Sahul Platform to the northwest and the Petrel Sub-basin and Darwin Shelf to the south (Figure 1). The Petrel Sub-basin was the principal depocentre during the Paleozoic, including a phase of north-west rifting in the Silurian to Carboniferous, but the Malita Graben did not form until the Early

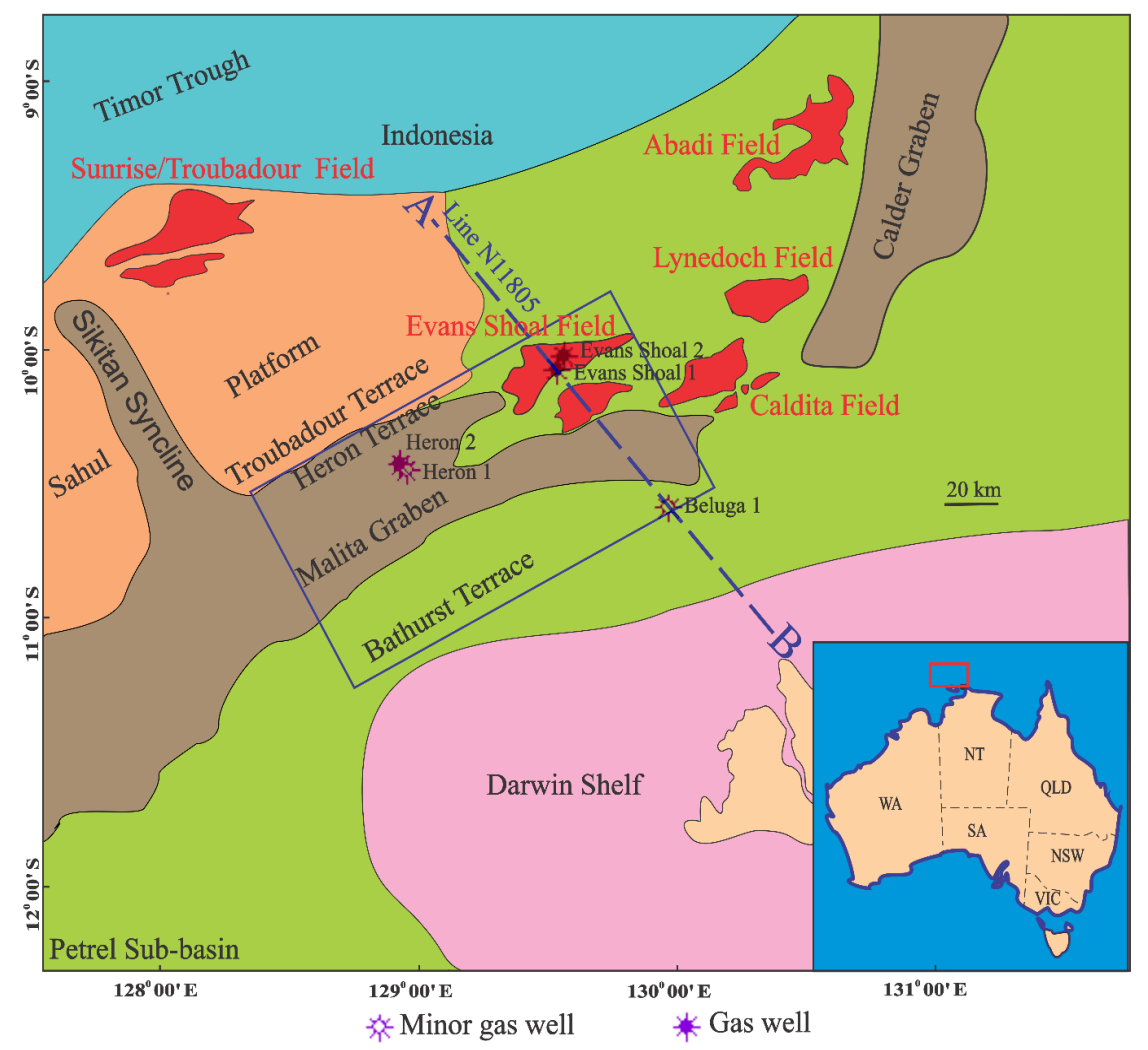

Figure 1. A schematic diagram showing the northern Bonaparte Basin with its major tectonic units, hydrocarbon discoveries, the location wells, and the Seismic Line N11805 (AB) of the Malita Graben. 
Mesozoic when north-east rifting commenced, intensifying in the Late Jurassic and culminating in break-up to the west in the Valanginian. Thermal history is vital to both maturity modeling and kinetic modeling. The study of thermal history is the precursor and presupposition to hydrocarbon generation history modeling. The Malita Graben contains several wells including Beluga 1, Heron 1, Heron 2, Evans Shoal 1 and Evans Shoal 2. The principal source rocks of the northern Bonaparte Basin encompass shales of the Early-Middle Jurassic Plover, upper-Middle to lower-Late Jurassic Elang and Late Jurassic to Early Cretaceous Frigate Shale (Cleia and Flamingo) formations [1] [2], and Lower Cretaceous Echuca Shoals Formation. The most important source rock in the Malita Graben occurred in the Plover Formation, which was also the most important reservoir target. [3] [4] have discussed the potential of this formation and its associate with hydrocarbons. The exploration of the field was started in 1971 with well Heron 1; the existence of substantial shows of hydrocarbons in the CretaceousUpper Jurassic section enhanced these intervals as potential source rocks in the offshore portion of the Bonaparte Gulf Basin. The second well Evans Shoal 1 discovered gas in low porosity sandstones of lower-Middle Jurassic Plover Formation. The source rock analysis suggested that the gas could have been derived from Jurassic or Early Cretaceous rocks in the vicinity of the well or further down-dip. The third well Beluga 1 encountered gas indications in the Bathurst Island Group, and gas shows within the Flamingo Group and Plover Formation. The fourth well Evans Shoal 2 was successful in meeting all objectives and established a maximum stable flow rate of $25.5 \mathrm{MMscf} / \mathrm{d}$ (Million standard cubic feet per day) showing presence of significant gas source. The recent drilling Heron 2 is reported as a gas discovery within the Elang and Plover formations [5]. These data urge us to investigate the potential of hydrocarbon generated from Jurassic to Early Cretaceous source rocks of the Malita Graben. Our study aimed at determining the thermal history and potential of hydrocarbon generated from the Plover, Elang, Frigate Shale, and Echuca Shoals formations source rocks of the Malita Graben.

\section{Geological Setting}

The geology history of the northern Bonaparte Basin have been described by [6] [7] and are summarized by [8] and is associated with three main phases of rifting. The oldest was initiated in the Paleozoic and has a northwesterly trend. Overprinting this is a Permo-Carboniferous episode of rifting, which created a northeasterly structural grain. A later phase of rifting related to "break-up", was initiated as early as the Late Triassic, but has its main expression from the Callovian to Kimmeridgian syn-rift (Figure 2). A number of significant regional discontinuities are recognized in the Middle, Late Jurassic and Early Cretaceous sequences, related to the effects of sea level fluctuations and 'break-up' along the north-western margin of Australia. The rapid subsidence in the Malita Graben was taken by the northeast-southwest trending faults in the northern Bonaparte Basin and was developed as its major Mesozoic depocentre. The average water depth in the Malita Graben is $79.35 \mathrm{~m}$ (meter). The structural architecture of the area is illustrated by regional seismic line oriented northwest to southeast across the Evans Shoal area and the well Beluga 1, and the thick Mesozoic section within the Malita Graben depocentre is shown on the northwest southeast dip line, which extends from the Sahul Platform throughout the Malita Graben to the Darwin Shelf (Figure 3). Mesozoic and Cenozoic sediments are probably up to 10,000 m thick in the Malita Graben and are underlain by a considerable section of Pennsylvanian-Permian sediments. The thick markedly Lower-Middle Jurassic Plover Formation sediments in the graben, possibly comprise good quality source rocks. The reservoir units in many of the commercial petroleum accumulations in the northern Bonaparte Basin are formed by the retrogradational deltaic sandstone deposits (Elang and Montara formations) during the onset of extension in the Middle Callovian caused by a widespread marine transgression. These marine sediments are gas-prone within the Malita Graben. Mudstones of the upper Middle Jurassic-Lower Neocomian Flamingo Group (Frigate Shale) provide additional source potential in the area. Early Cretaceous to Paleogene (post-rift) thermal subsidence, including the Lower Cretaceous Echuca Shoals Formation may have some source potential in the graben. The Cretaceous-Cenozoic section exceeds $4000 \mathrm{~m}$ in thickness in the central Malita Graben. Miocene to Holocene convergence of the Indo-Australian and Southeast Asian plates has resulted in the formation of a major tectonic collision zone (Banda Orogen), the 2000 - $3000 \mathrm{~m}$ deep Timor Trough and widespread fault reactivation across the western of the Bonaparte Basin.

\section{Materials and Methods}

\subsection{Materials and Input Parameters}

The materials and input data required to run into the BasinMod 1-D of our study comprise the present thick 


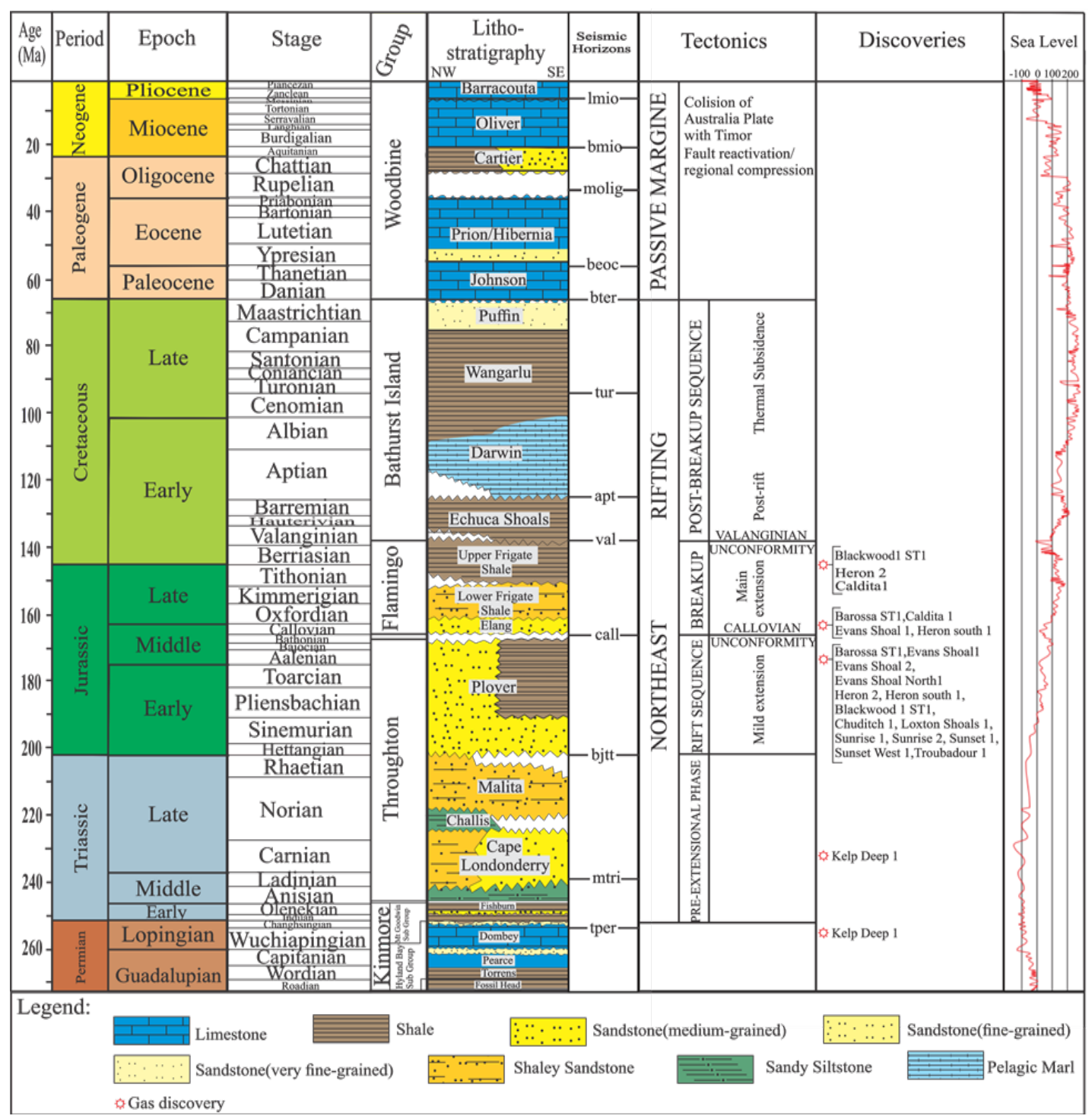

Figure 2. Stratigraphyand petroleum discoveries of the northern Bonaparte Basin, based on the Bonaparte Basin Biozonation and Stratigraphy Chart 33 (Kelman et al., 2014), showing the short term sea level used for burial history modelled. Geologic Time Scale after Gradstein et al. (2012).

nesses of each stratigraphic unit, top and base wellbore depths, and the lithology mixes data are derived from composite well logs (Table 1). Biostratigraphy is derived from the ditch cuttings, sidewall cores and conventional cores were washed, separated and analyzed for micro fauna (Foraminifera) and flora (spores and pollens) to attribute a presumed age to each interval studied, kerogen types, total organic carbon (TOC), kinetic algorithms and results of pyrolysis analyses, the location of wells, and organic thermal indicators include vitrinite reflectance values; the water-sediment interface temperatures after [9] and subsurface bottom hole temperatures (BHTs) through time, the short term sea level proposed by [10]-[12], geologic time scale 1989 Harland, the density of asthenosphere $\left(\rho_{\mathrm{m}}\right)$ and water $\left(\rho_{\mathrm{w}}\right)$ are $3.40 \mathrm{~g} / \mathrm{cm}^{3}$ and $1.03 \mathrm{~g} / \mathrm{cm}^{3}$ respectively, the Beta factor $(\beta)$ and thickness of lithosphere (a) can be obtained accepting default values of 2 and $125 \mathrm{~km}$, respectively, all mixed parameters, the initial porosity, reciprocal and exponential compaction factors, the matrix density, matrix thermal conductivity, and matrix heat capacity are adopted from the default values in BasinMod Software package. The input data and materials for BasinMod 2-D are 1-D well data,Seismic Line N11805, map coordinates, reference location of all data including faults, names and age ranges of all layers, lithologic characteristics of facies within the layers. The input parameters for Basin View are Basin Mod 1-D transient heat flow values. 


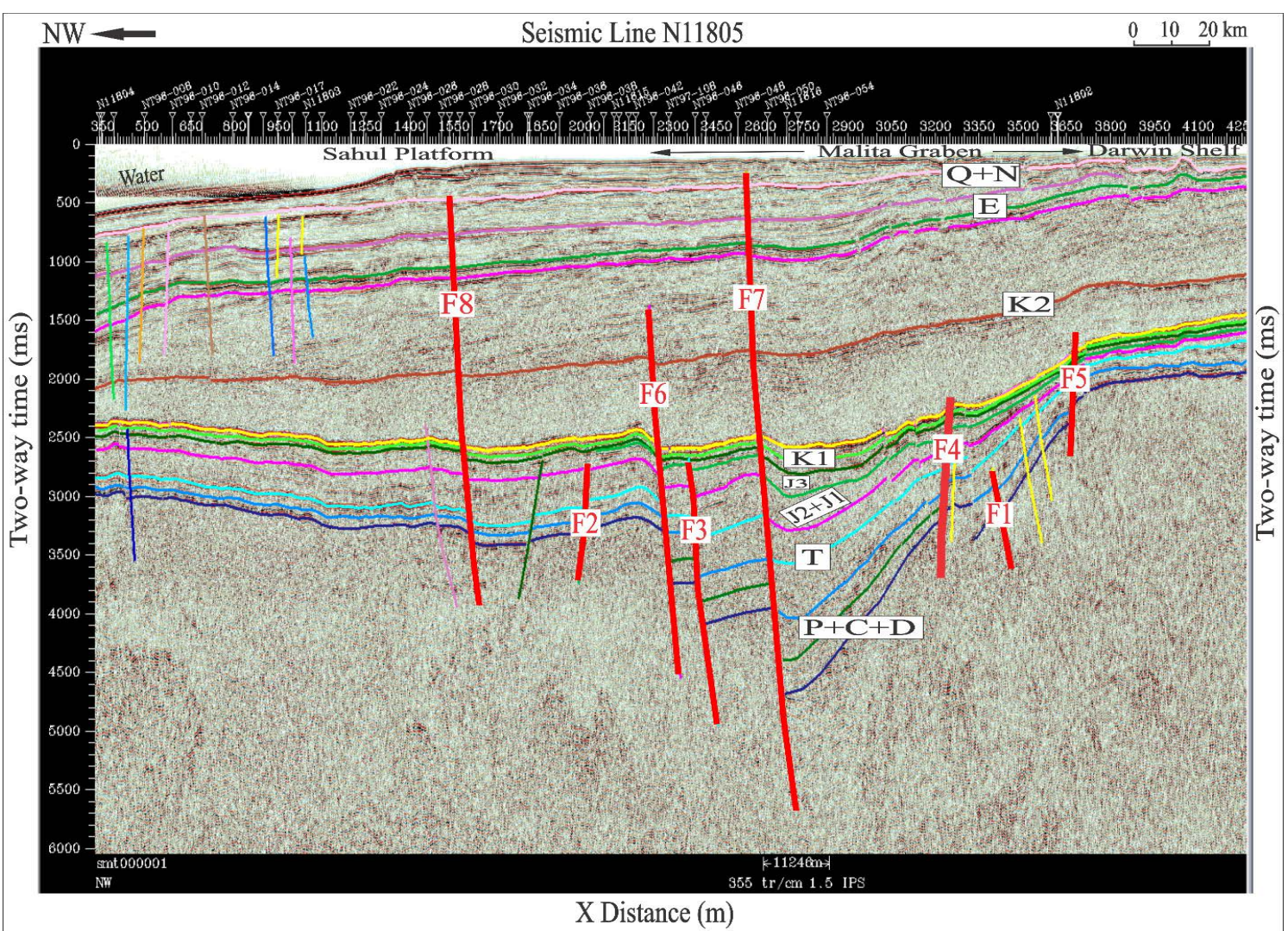

Figure 3. Two-dimensional Seismic Line N11805. Location shown in Figure 1. The key stratigraphic horizons written in black capital alphabets as follows: $\mathrm{Q}+\mathrm{N}=$ Oliver, Barracouta and Alaria formations, $\mathrm{E}=$ Johnson, Hibernia and Cartier formations, $\mathrm{K}_{2}=$ Vee Formation, $\mathrm{K}_{1}=$ Echuca Shoals, Darwin, Jamieson and Wangarlu formations, $\mathrm{J}_{3}=$ Elang, Cleia and Flamingo formations, $\mathrm{J}_{2}+\mathrm{J}_{1}=$ Plover Formation, $\mathrm{T}=$ Malita, Pollard and Mt Goodwin formations and $\mathrm{P}+\mathrm{C}+\mathrm{D}=\mathrm{Hyland}$ Bay Formation, while the faults are segregated by red color of the letter (F1to F8).

\subsection{Methods}

\subsubsection{One-Dimensional Basin Mod}

The compaction has the most significant impact on thermal history, which affects the timing of source rock maturity and hydrocarbon generation. The exponential factor expresses how much a specific lithology will be reduced in thickness and this was calculated following the equation of [13] that assumes porosity changes proportionally to the change in sediment load:

$$
\phi=\phi_{0} \exp ^{(-K Z)}
$$

where: $\phi$ is porosity $(\%)$.

$\phi_{0}$ is initial porosity (\%).

$K$ is compaction factor adjusted for varying compressibilities of different lithologies $\left(\mathrm{m}^{-1}\right)$.

$Z$ is depth $(\mathrm{m})$.

Mathematical method comprises the equations of backstripping and tectonic subsidence [14] is used to reconstruct the burial history:

$$
\begin{gathered}
D t=\left[S \frac{\left(\rho_{m}-\rho_{s}\right)}{\left(\rho_{m}-\rho_{w}\right)}-\Delta S L \frac{\rho_{w}}{\left(\rho_{m}-\rho_{w}\right)}\right]+\left(W_{d}-\Delta S L\right) \\
\rho_{s}=\frac{\sum_{i}\left[\phi_{i} \rho_{w}+\left(1-\phi_{i}\right) \rho_{s g i}\right] S_{i}}{S}
\end{gathered}
$$


Table 1. Geological layers, top and base depths for Beluga 1, Heron 1, Evans Shoal 1 and Evans Shoal 2 Wells and lithology used as input parameters for the BasinMod 1D. Lithological data were compiled from their composite well logs.

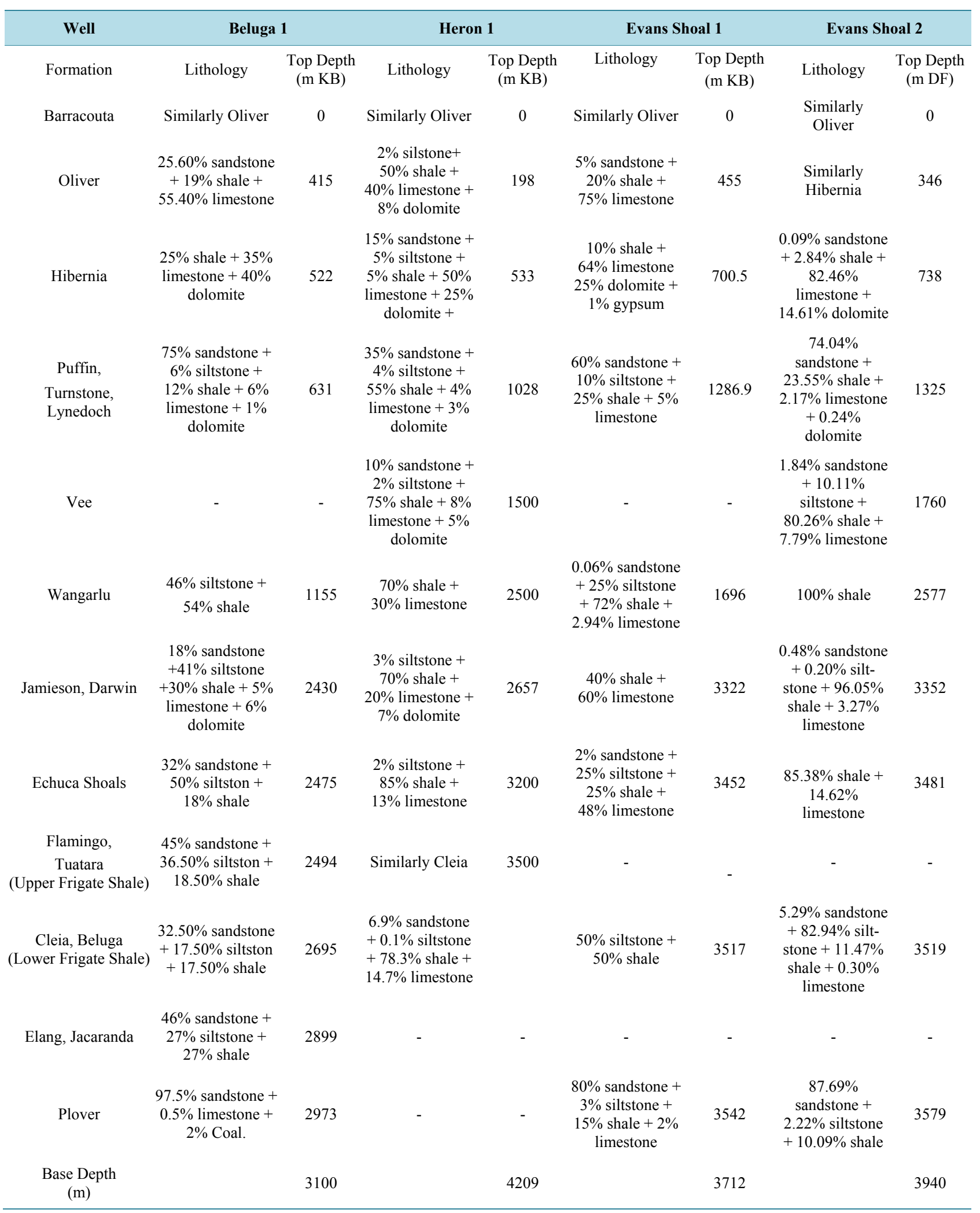

- is no data. DF is $22 \mathrm{~m}$ above sea level. KB is Kelly Bushing. 
where: $D t$ is the amount of tectonic subsidence (water column $(\mathrm{m})$ in past time).

$S$ is the total stratigraphic thickness of the sediment column corrected for compaction (m).

$\rho_{s}$ is the average density of the sediment stratigraphic column $\left(\mathrm{g} / \mathrm{cm}^{3}\right)$.

$W_{d}$ is the palaeo-water depth (m).

$\triangle S L$ is the relative increment for eustatic sea-level variation (m).

$\rho_{m}$ is the density of asthenosphere $\left(\mathrm{g} / \mathrm{cm}^{3}\right)$.

$\rho_{w}$ is the density of water $\left(\mathrm{g} / \mathrm{cm}^{3}\right)$.

$\phi_{i}$ is the porosity of stratigraphic unit $i$ (dimensionless).

$\rho_{s g i}$ is the grain density of stratigraphic unit $i\left(\mathrm{~g} / \mathrm{cm}^{3}\right)$.

$S_{i}$ is the thickness of stratigraphic unit $i$ after compaction correction (m).

BasinMod 1-D technique is used to restructure burial and thermal histories and the processes of hydrocarbon generation that determine the maturation parameters, such as the time of onset, peak, and end of oil generation and wet gas window. The models used are:

The change in temperature with depth of the study area. The relationship is:

Geothermal gradient $\left({ }^{\circ} \mathrm{C} / \mathrm{m}\right)=$ Change in temperature $\left({ }^{\circ} \mathrm{C}\right) /$ change in depth $(\mathrm{m})$

The transient heat flow equation is used to represent thermal conduction and convection supposing that the heat transfer in $1 \mathrm{D}$ is by vertical conduction using the following equation:

$$
\begin{gathered}
\frac{\mathrm{d} T(x, t)}{\mathrm{d} t}=\frac{\mathrm{d}}{\mathrm{d} x}\left(\alpha(x) \frac{\mathrm{d} T}{\mathrm{~d} x} Q\right) \\
\alpha(x)=\frac{k}{\rho c}
\end{gathered}
$$

where: $\alpha$ is thermal diffusivity, $T$ is temperature $(\mathrm{K}), \quad k$ is thermal conductivity $\left(\mathrm{W} / \mathrm{m} \cdot{ }^{\circ} \mathrm{C}\right), c$ is heat capacity $\left(\mathrm{kJ} / \mathrm{m}^{3} \cdot{ }^{\circ} \mathrm{C}\right), \rho$ is density $\left(\mathrm{g} / \mathrm{cm}^{3}\right), Q$ is heat generation $(\mathrm{mg} / \mathrm{g}$ TOC) and $x$ is depth $(\mathrm{m})$.

BasinMod 1-D offers a rifting heat flow option that is a simplification of the [15] finite rifting model which, certainly not without skeptics, is probably the most widely accepted theory [16], as well as somewhat fewer difficult to employ. The thermal decay equation is used for rifting heat flow:

$$
F(t)=\frac{k T_{1}}{z} \cdot\left\{1+\pi \sum_{n=1}^{\infty} n b_{n}(-1)^{n-1} \times \exp \left[-n^{2} \pi^{2}(t-\Delta t) k / a^{2}\right]\right\}
$$

where: $F(t)$ is Heat Flux at surface at time $t\left(\mathrm{~mW} / \mathrm{m}^{2}\right), t$ is time of rifting (Ma), $k$ is thermal conductivity

$\left(\mathrm{W} / \mathrm{m} \times{ }^{\circ} \mathrm{C}\right), \frac{k T_{1}}{z}$ is heat flow prior to rifting, based on present day heat flow, $b_{n}$ is coefficient (Eigenvalue), $a$ is thickness of lithosphere, default is $125 \mathrm{~km}$. One requirement for the calculating of rifting heat flow in BasinMod 1-D is a Beta factor $(\beta)$, which is defined as:

$\beta=$ initial lithospheric thickness/lithospheric thickness immediately after stretching and can be obtained by accepting the default value of two (2).

Modified [17] by [18], hydrogen index (HI) versus oxygen index (OI), is used for characterization of kerogentypes, potential yield (S1 + S2) versus total organic carbon (TOC) for potential generating hydrocarbon, and Ro\% versus Depth for thermal maturity.

Maturity history will be simulated based on the burial history reconstructed in the geohistory model. The methodology involves derivation of the heat flow history using the present-day observed temperatures with paleo-temperature indicator data (such as vitrinite reflectance Ro) and adjusting them against the computed maturity and thermal curves until best-fit models are reached, which considered representing the thermal history experienced by the sediments in the past [19].

Maturation and hydrocarbon generation model:

Predicted maturation and timing of hydrocarbon generation are based on Lawrence Livermore National Laboratory (LLNL) vitrinite and kerogen kinetics.

\subsubsection{Two-Dimensional Basin Mod}

Two-dimensional modeling is scanned input 2-D Seismic Line N11805 that crosses the study area in the north- 
west-southeast trend comprising eight stratigraphic horizons that best depicts the structure, temperature, maturity, and generation histories. Whereas Two-Way-Time (milliseconds) conversions to depths in meters is done outside of Basin Mod 2-D.

Basin View takes Basin Mod 1-D, gridded data, or scattered X, Y, Z, data, which allows us to calculate surface and to draw the isoline of present day heat flow.

\section{Results and Discussion}

\subsection{Thermal History}

\subsubsection{Geothermal Gradient}

A total of thirty two (32) measured temperatures were obtained from four wells, which were analyzed and interpreted to investigate the thermal history of the Malita Graben. The top and bottom depths temperatures according to this linear relationship are used to calculate the gradient to avoid seasonal variation in surface temperatures [20]. The results of bottom hole temperatures (BHTs) analysis have shown that there is a differential distribution of the geothermal gradient among the wells in the study area. The well Beluga 1 reached a total depth of $3100 \mathrm{~m} \mathrm{~KB}$ (Kelly Bushing) within the Plover Formation, and the calculated extrapolated static bottom hole temperature of $122.32^{\circ} \mathrm{C}$, with temperature gradient of $3.05^{\circ} \mathrm{C} / 100 \mathrm{~m}$ (Sea bed temperature was $27.80^{\circ} \mathrm{C}$ ), measured by an applied microsystems 12 (Broken Hill Proprietary Petroleum Pty Ltd, 04/06/1991). The well Heron 1 reached a total depth of $4209 \mathrm{~m} \mathrm{~KB}$ within Petrel (Frigate) Formation, and the calculated extrapolated static bottom hole temperature is reported as $183^{\circ} \mathrm{C}$, with a temperature gradient of $3.87^{\circ} \mathrm{C} / 100 \mathrm{~m}$ (sea bed temperature is assumed to be $20^{\circ} \mathrm{C}$ ). The well Evans Shoal 1 reached a total depth of $3712 \mathrm{~m} \mathrm{~KB}$ within the Plover Formation, with a calculated extrapolated static bottom hole temperature of $170^{\circ} \mathrm{C}$ and a temperature gradient of $4.04^{\circ} \mathrm{C} / 100 \mathrm{~m}$ (sea bed temperature is assumed to be $20^{\circ} \mathrm{C}$ ), similarly the Evans Shoal 2 well reached a total depth of $3940 \mathrm{~m}$ DF within the Plover Formation, with a calculated extrapolated static bottom hole temperature of $179.67^{\circ} \mathrm{C}$, with a geothermal gradient of $4.05^{\circ} \mathrm{C} / 100 \mathrm{~m}$, and sea bed temperature is assumed to be $20^{\circ} \mathrm{C}$ (Figure 4). The regional geothermal gradient average of $3.75^{\circ} \mathrm{C} / 100 \mathrm{~m}$ is obtained in the Malita Graben, northern Bonaparte Basin. The lower geothermal gradient $\left(3.05^{\circ} \mathrm{C} / 100 \mathrm{~m}\right)$ is located in the well Beluga 1 , in the southeast of the Malita Graben and maximum geothermal gradient $\left(4.05^{\circ} \mathrm{C} / 100 \mathrm{~m}\right)$ is located in well Evans Shoal 2 on a terrace north of the study area. These dissimilarities in geothermal gradients may reflect the changes in the thermal conductivity of the source rocks and the presence of intrusive bodies in the Malita Graben.

\subsubsection{Temperature Evolution}

BasinMod 2-D is used to predict temperature evolution in the Malita Graben utilizing the Seismic Line N11805. The temperature of the source rocks along this Seismic Line interpreted to have been initiated at a level of less than $80^{\circ} \mathrm{C}$ and concluded at a level of $200^{\circ} \mathrm{C}-275^{\circ} \mathrm{C}$. The temperature evolution history can be described as follows: At $90 \mathrm{Ma}$ the temperature of less than $80^{\circ} \mathrm{C}$ occurred at the base of Echuca Shoals Formation source rock throughout the study area, and in the south margin took place at the base of Upper Frigate Shale Formation source rock, while the temperature of $80^{\circ} \mathrm{C}-100^{\circ} \mathrm{C}$ at its base in the center and the north margin of the study area. The temperature of $80^{\circ} \mathrm{C}-100^{\circ} \mathrm{C}$ occurred at the base of Lower Frigate Shale Formation source rock in the south margin and the temperature of $100^{\circ} \mathrm{C}-130^{\circ} \mathrm{C}$ at its base in the center and the north margin of the study area. The temperature of $100^{\circ} \mathrm{C}-130^{\circ} \mathrm{C}$ occurred at the base of Elang Formation source rock throughout the study area. The temperature of $100^{\circ} \mathrm{C}-130^{\circ} \mathrm{C}$ took place at the base of Plover Formation source rock in the south margin and the temperature of $130^{\circ} \mathrm{C}-150^{\circ} \mathrm{C}$ at its base in the center and the north margin, and increased with depth and reached a maximum value of $275^{\circ} \mathrm{C}$ at the base of $\mathrm{P}+\mathrm{C}+\mathrm{D}$ in the center of Malita Graben (Figure 5(a)). At $65 \mathrm{Ma}$, the temperature of $80^{\circ} \mathrm{C}-100^{\circ} \mathrm{C}$ occurred at the base of Echuca Shoals and Upper Frigate Shale formations source rocks in the south margin and the temperature of $100^{\circ} \mathrm{C}-130^{\circ} \mathrm{C}$ at their base in the center and the north margin of the study area. The temperature of $100^{\circ} \mathrm{C}-130^{\circ} \mathrm{C}$ occurred at the base of Lower Frigate Shale and Elang formations source rocks in the south margin and the temperature of $130-150^{\circ} \mathrm{C}$ at their base in the center and the north margin of the study area. The temperature of $100^{\circ} \mathrm{C}-130^{\circ} \mathrm{C}$ occurred at the base of the Plover Formation source rock in the south margin and the temperature of $150^{\circ} \mathrm{C}-200^{\circ} \mathrm{C}$ at its base in the center and the north margin and increased with depth and reached a maximum value of $275^{\circ} \mathrm{C}$ at the base of 

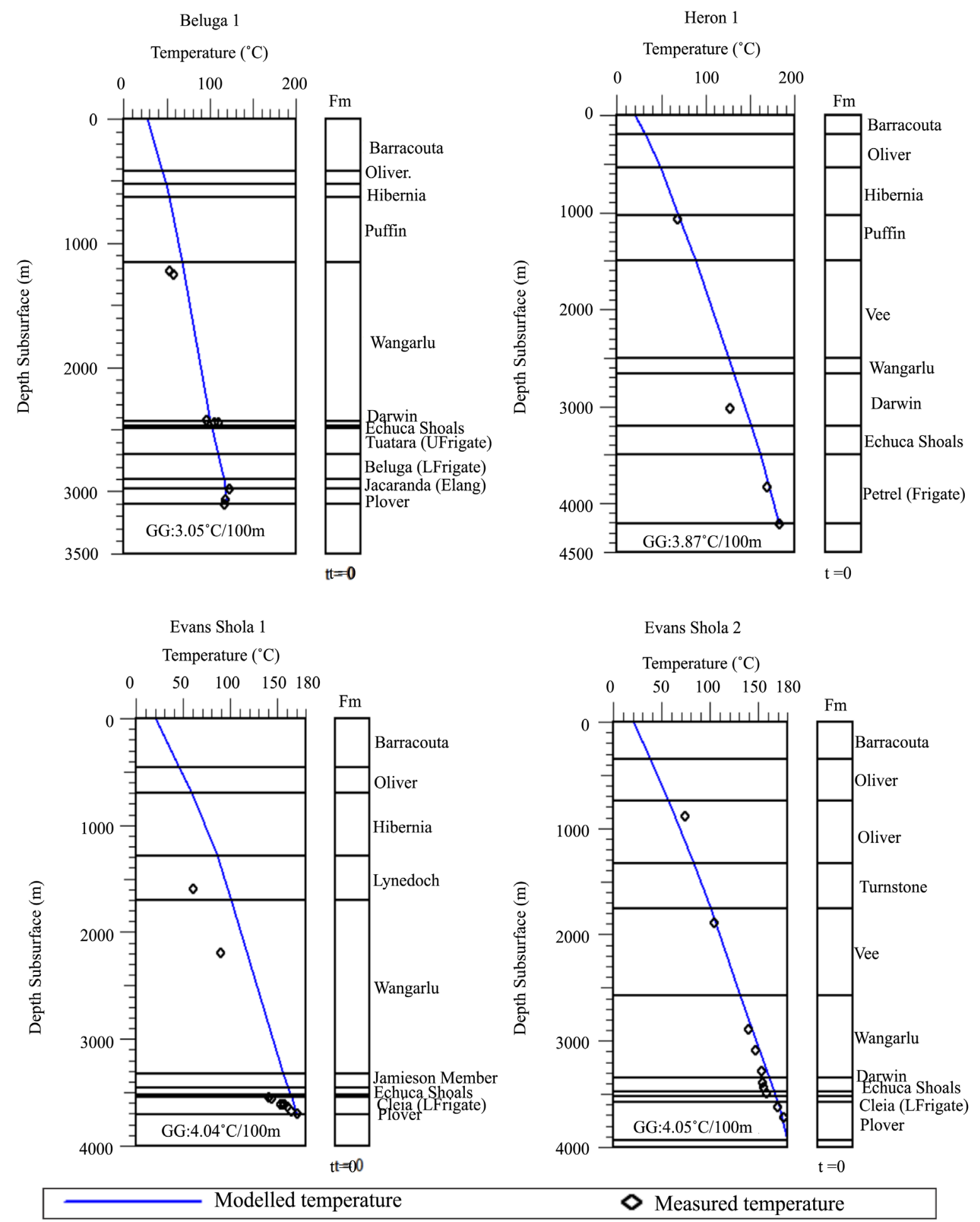

Figure 4. Measured values and Modelled trends of the present-day temperature showing the geothermal gradient for four wells in the Malita graben. GG: Geothermal Gradient; UFrigate: Upper Frigate Shale (Flamingo Formation); LFrigate: Lower Frigate Shale (Cleia Formation); Frigate: Lower and Upper Frigate Shales; Fm: Formation.

$\mathrm{P}+\mathrm{C}+\mathrm{D}$ in the center of the study area (Figure 5(b)). At $23.3 \mathrm{Ma}$, the temperature of $80^{\circ} \mathrm{C}-100^{\circ} \mathrm{C}$ took place at the base of Echuca Shoals Formation source rock in the south margin and the temperature of $100^{\circ} \mathrm{C}-130^{\circ} \mathrm{C}$ at 


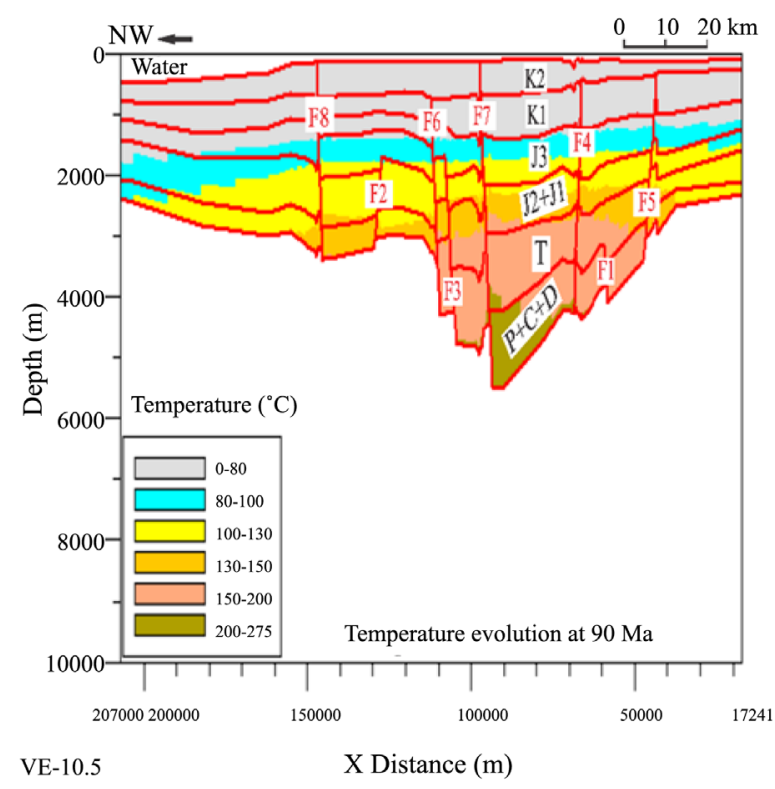

(a)

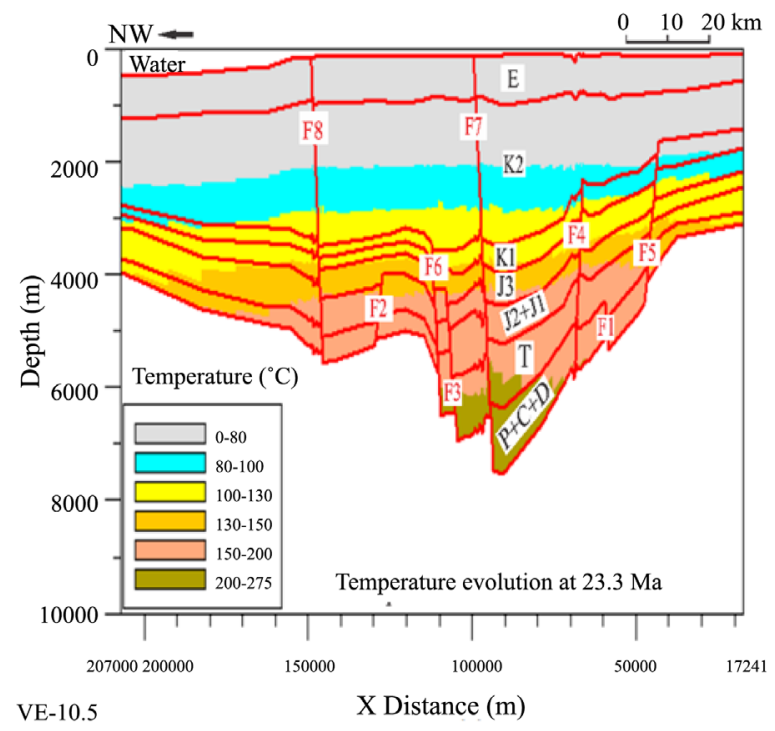

(c)

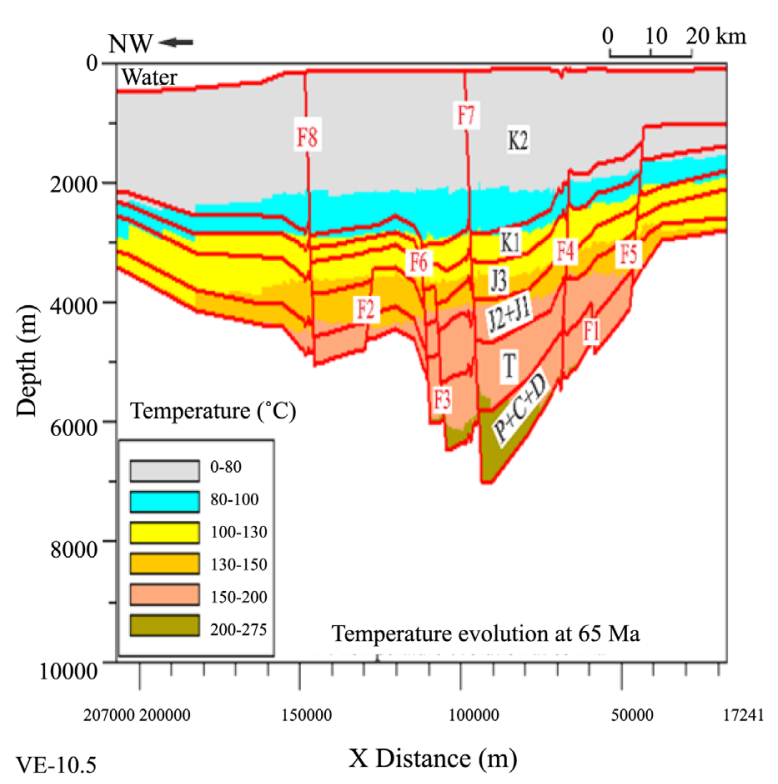

(b)

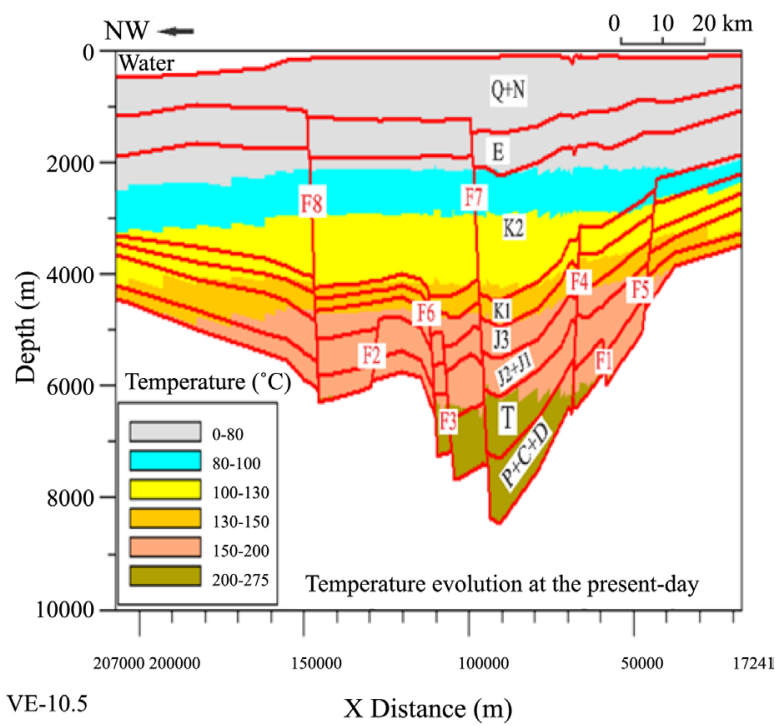

(d)

Figure 5. Schematic diagrams showing temperature evolution history of the Malita Graben obtained from Seismic Line N11805. (a) Temperature evolution at $90 \mathrm{Ma}$; (b) Temperature evolution at $65 \mathrm{Ma}$; (c) Temperature evolution at $23.3 \mathrm{Ma}$ and (d) Temperature evolution at the present-day. The key stratigraphic horizons written in black capital alphabets as follows: Q $+\mathrm{N}=$ Oliver, Barracouta and Alaria formations, $\mathrm{E}=$ Johnson, Hibernia and Cartier formations, $\mathrm{K}_{2}=$ Vee Formation, $\mathrm{K}_{1}=$ Echuca Shoals, Darwin, Jamieson and Wangarlu formations, $\mathrm{J}_{3}=$ Elang and Frigate (Cleia and Flamingo) formations , $\mathrm{J}_{2}+\mathrm{J}_{1}$ $=$ Plover Formation, $\mathrm{T}=\mathrm{Mt}$ Goodwin, Pollard and Malita formations and P $+\mathrm{C}+\mathrm{D}=$ Hyland Bay Formation, while the faults are segregated by red color of the letter F (F1 to F8).

its base in the center and the north margin of the study area. The temperature of $100^{\circ} \mathrm{C}-130^{\circ} \mathrm{C}$ occurred at the base of the Frigate Shale and Elang formations source rocks in the south margin and the temperature of $130^{\circ} \mathrm{C}$ $150^{\circ} \mathrm{C}$ at their base in the center and the north margin of the study area. The temperature of $100^{\circ} \mathrm{C}-130^{\circ} \mathrm{C}$ took place at the middle of the Plover Formation source rock in the south margin and the temperature of $150^{\circ} \mathrm{C}$ $200^{\circ} \mathrm{C}$ at its base in the center and the north margin and reached a maximum value of $275^{\circ} \mathrm{C}$ at the base of $\mathrm{P}+\mathrm{C}$ $+\mathrm{D}$ in the center of the study area (Figure 5(c)). At the present-day the temperature of $100^{\circ} \mathrm{C}-130^{\circ} \mathrm{C}$ occurred 
at the top of Echuca Shoals Formation source rock in the south margin and the temperature of $130^{\circ} \mathrm{C}-150^{\circ} \mathrm{C}$ at its base in the center and the north margin of the study area. The temperature of $100^{\circ} \mathrm{C}-130^{\circ} \mathrm{C}$ occurred at the base of the Frigate Shale and Elang formations source rocks in the south margin and the temperature of $150^{\circ} \mathrm{C}$ $200^{\circ} \mathrm{C}$ at their base in the center and the north margin of the study area. The temperature of $100^{\circ} \mathrm{C}-130^{\circ} \mathrm{C}$ took place at the top of Plover Formation source rock in the south margin and the temperature of $150^{\circ} \mathrm{C}-200^{\circ} \mathrm{C}$ at its base in the center and north margin and increased with depth and reached a maximum value of $275^{\circ} \mathrm{C}$ at the base of $\mathrm{P}+\mathrm{C}+\mathrm{D}$ in the center of the study area (Figure 5(d)). The modeling results are calibrated to the measured temperature values for the wells Beluga 1, Heron 1, Evans Shoal 1, Evans Shoal 2 and to the Seismic Line N11805 (Figure 4 and Figure 5). The correspondence between the simulated and the measured temperature values is remarkably good, which indicates that the accuracy is relatively higher for both $1 \mathrm{D}$ and $2 \mathrm{D}$ modeling.

\subsubsection{Heat Flow}

The present day heat flow (Figure 6) was calculated from sea bottom temperatures, bottom hole temperatures and modelled sediment thermal conductivity. The present day heat flows generally range from 46.23 to 61.99 $\mathrm{mW} / \mathrm{m}^{2}$. Heat flow history is simulated using transient modeling taking into account the time-dependent top and bottom boundary conditions which are based on basal heat flow history that were reconstructed by forward modeling of tectonic subsidence. The heat flow model for each well is constrained by available and observed data, BHTs, and thermal conductivities of lithotypes according to intersected lithologies, which in turn required the modeling of vertical heat transfer through the sediments. The modeling results show that the present day heat flow values in the wells Beluga 1, Heron 1, Evans Shoal 1, and Evans Shoal 2 are $46.23 \mathrm{~mW} / \mathrm{m}^{2}, 57.76 \mathrm{~mW} / \mathrm{m}^{2}$, $59.17 \mathrm{~mW} / \mathrm{m}^{2}$, and $61.99 \mathrm{~mW} / \mathrm{m}^{2}$ respectively. Presently the regional heat flow average of $59.06 \mathrm{~mW} / \mathrm{m}^{2}$ is obtained in the study area. The highest present-day heat flow values occurred on a terrace north of the Malita Graben, this most likely indicates that hot fluids are currently variably migrating into this structure. Lower heat flow value has been modeled in the well Beluga1, in the southeast sites of the Malita Graben.

The northern Bonaparte Basin experienced several deformation phases including lithospheric thinning, hence, heat flow is expected to vary over the geological history of the basin; mostly showing increase at the times of rifting from Middle to Late Jurassic period, the main expression in Callovian and Kimmeridgian age and decrease in the post-rift phases. The higher paleo-heat flow values change from 83.54 to $112.01 \mathrm{~mW} / \mathrm{m}^{2}$ with an average of $101.71 \mathrm{~mW} / \mathrm{m}^{2}$ during rift event were sufficient for the source rocks maturation and hydrocarbon generation during Cretaceous post-breakup sequence (post-rift) in the Malita Graben (Figure 7).

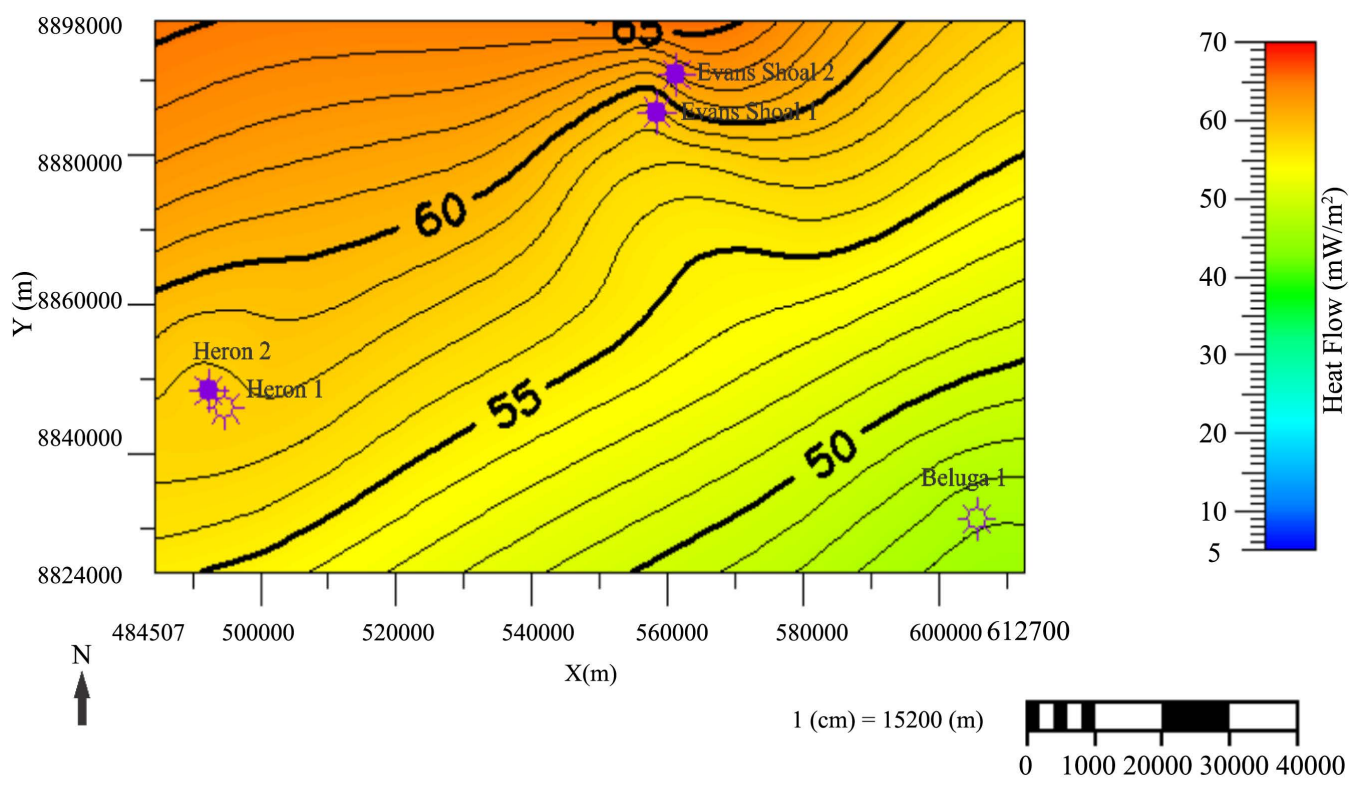

(m) 


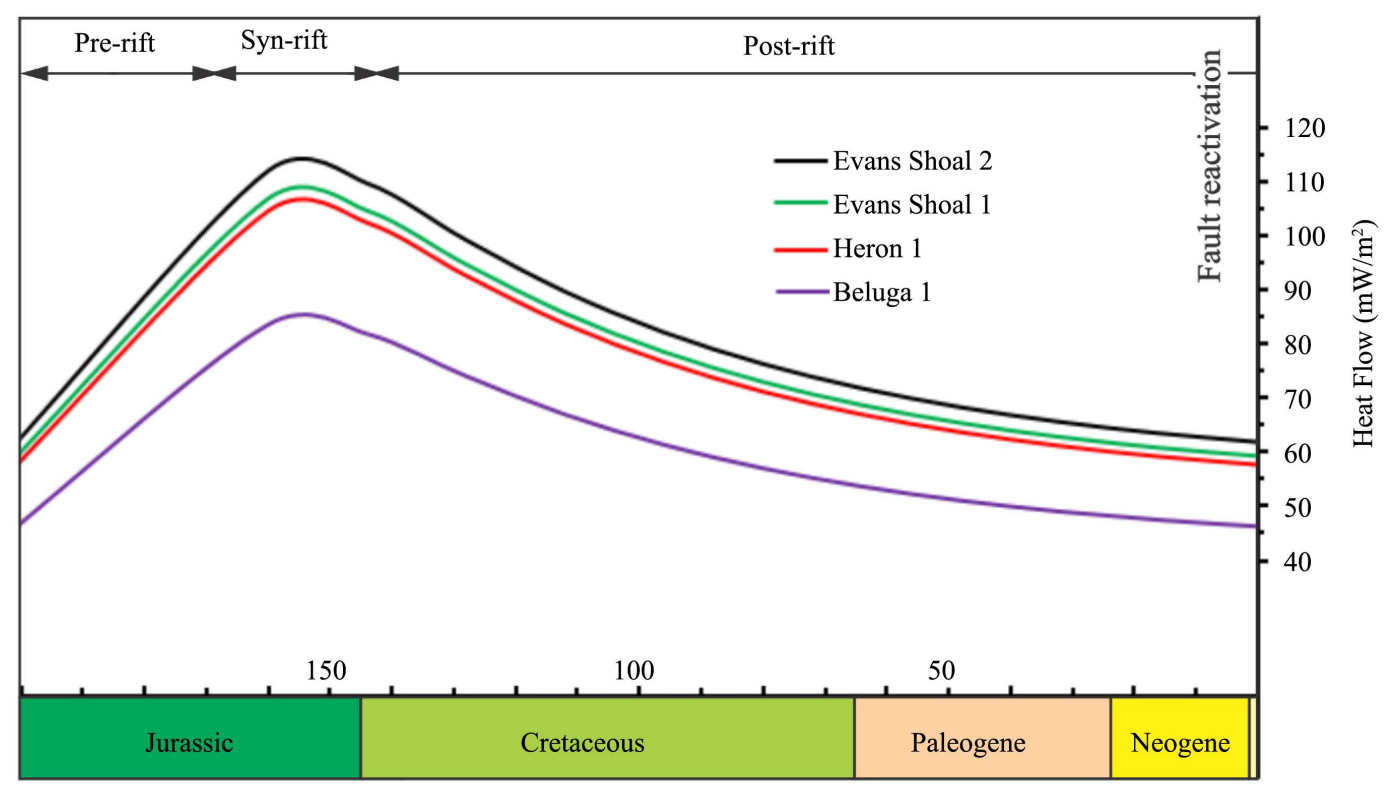

Age (Ma)

Figure 7. Paleo-heat flow curves for four wells in the Malita Graben.

\subsection{Source Rock Richness and Hydrocarbon Generation Potential}

The measurements of total organic carbon (TOC) and thermal cracking of the organic matter by pyrolysis (S1 and $\mathrm{S} 2 \mathrm{mg} \mathrm{HC/g}$ rock) are essential in evaluating source rock richness and hydrocarbon generation potential were carried out as stated by the standard guidelines suggested by [21]. The Tuatara (UFrigate) Formation source rock in the well Beluga 1 contains two (2) TOC and S1 + S2 values ranging from 0.67 to $1.08 \mathrm{wt} \%$ with an average of $0.88 \mathrm{wt} \%$ and from 2.2 to $3.75 \mathrm{mg} \mathrm{HC} / \mathrm{g}$ rock with an average of $2.98 \mathrm{mg} \mathrm{HC} / \mathrm{g}$ rock, respectively (Table 2). These values indicate that the Tuatara (UFrigate) Formation is a fair to good source rock with poor to fair hydrocarbon generative potential,and the Beluga (LFrigate) Formation source rock has four (4) TOC, which vary from 0.20 to $0.54 \mathrm{wt} \%$ whith an average of $0.38 \mathrm{wt} \%$, showing a poor-to-fair source rock, hence the poor hydrocarbon generation potential. Similarly, the Jacaranda (Elang) Formation, two (2) readings TOC, varying from 0.37 to $0.49 \mathrm{wt} \%$, that have the mean value of $0.48 \mathrm{wt} \%$, indicating a poor source rock, therefore the poor hydrocarbon generating potential should be shown. The Plover Formation in the well Beluga 1 gave a TOC value of $0.61 \mathrm{wt} \%$ and S1 + S2 of $1.97 \mathrm{mg} \mathrm{HC} / \mathrm{g}$ rock, indicating a fair source rock with poor hydrocarbon generative potential (Figure 8(a)). It is uncommon for sediments from northern Bonaparte Basin with less than 1 per cent Total Organic Carbon to represent significant hydrocarbon source rocks, thus the Beluga (LFrigate), Jacaranda (Elang) and Plover Formation are a poor-to-fair source richness with poor hydrocarbon generation potential in the southeast of the Malita Graben. The Echuca Shoals Formation in the well Heron 1 comprises thirty two (32) TOC ranging from 0.34 to $4.45 \mathrm{wt} \%$ with an average of $2.02 \mathrm{wt} \%$, and twenty five (25) S1 + S2 varying from 0.25 to $7.82 \mathrm{mg} \mathrm{HC} / \mathrm{g}$ rock with an average of $1.60 \mathrm{mg} \mathrm{HC} / \mathrm{g}$ rock, indicating a poor-to-very good organic richness with poor-to-good hydrocarbon generative potential. The Petrel (Frigate Shale) Formation contains fifty eight (58) TOC ranging from 0.56 to $26.40 \mathrm{wt} \%$ with an average of $3.44 \mathrm{wt} \%$, and twenty nine (29) $\mathrm{S} 1+\mathrm{S} 2$ ranging from 0.43 to $23.90 \mathrm{mg} \mathrm{HC} / \mathrm{g}$ rock with an average of $2.17 \mathrm{mg} \mathrm{HC} / \mathrm{g}$ rock, indicating a fair-tovery good source rock with poor-to-very good hydrocarbon generating potential (Figure 8(a)). The Echuca Shoals Formation in the well Evans Shoal 1 contains five (5) TOC and S1 + S2 ranging from 0.90 to $2.29 \mathrm{wt} \%$ with an average of $1.63 \mathrm{wt} \%$ and from 0.47 to $1.07 \mathrm{mg} \mathrm{HC} / \mathrm{g}$ rock with an average of $0.74 \mathrm{mg} \mathrm{HC} / \mathrm{g}$ rock, indicating fair-to-very good source rock with poor hydrocarbon generative potential. Similarly, the Echuca Shoals Formation in the well Evans Shoal 2 comprises five (5) TOC and S1 + S2 ranging from 0.59 to $2.05 \mathrm{wt} \%$ with an average of $1.39 \mathrm{wt} \%$ and from 1.08 to $2.51 \mathrm{mg} \mathrm{HC} / \mathrm{g}$ rock with an average of $2.02 \mathrm{mg} \mathrm{HC} / \mathrm{g}$ rock. The Plover Formation in the well Evans Shoal 1 has six (6) TOC and S1 + S2 varying from 0.85 to $5.72 \mathrm{wt} \%$ with an aver- 


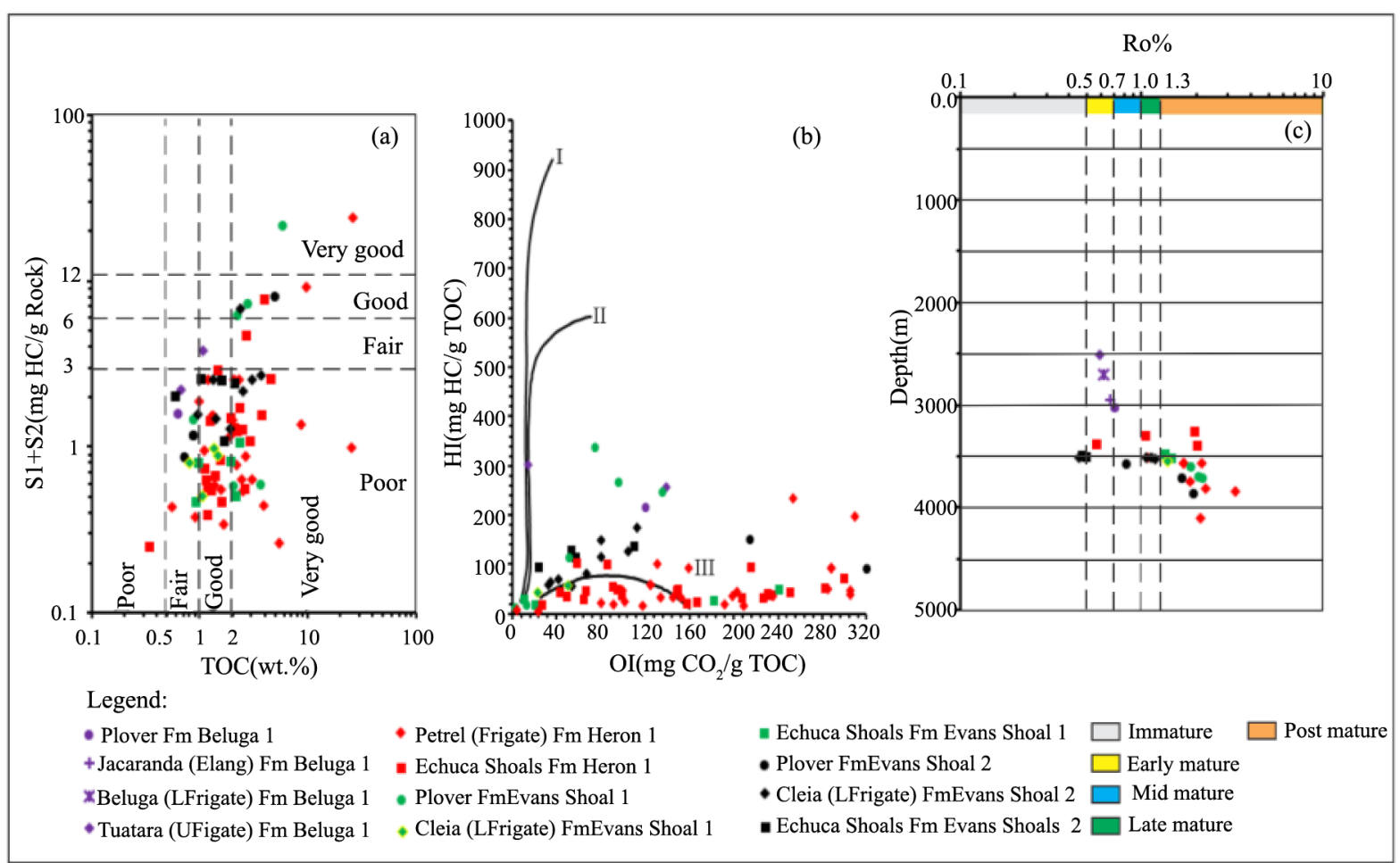

Figure 8. (a) Plot of potential yield S1 + S2 versus Total Organic Carbon (TOC) for the hydrocarbon generation potential; (b) Hydrogen Index (HI) versus Oxygen Index (OI) for organic matter types and (c) Vitrinate reflectance Ro\% versus Depth showing thermal maturity ofthe Plover, Elang, Frigate Shale, and Echuca Shoals formations source rocks of the Malita Graben.

Table 2. TOC data and Rock Eval Pyrolysis parameters for the Malita Graben source rock samples.

\begin{tabular}{|c|c|c|c|c|c|c|c|c|}
\hline Well & Depth (m) & Formation & Lithology & TOC (wt. \%) & HI (mg/g) & OI (mg/g) & $\mathrm{S} 1+\mathrm{S} 2(\mathrm{mg} / \mathrm{g})$ & $\mathrm{S} 2 / \mathrm{S3}$ (mg/g) \\
\hline \multirow[t]{4}{*}{ Beluga 1} & $2499.50-2515.50$ & $\begin{array}{l}\text { Tuatara } \\
\text { (UFrigate) }\end{array}$ & Claystone & $\frac{0.67-1.08}{0.88(2)}$ & $\frac{256.72-302.78}{279.75(2)}$ & $\frac{13.89-138.81}{76.35(2)}$ & $\frac{2.20-3.75}{2.98(2)}$ & $\frac{1.85-21.8}{11.82(2)}$ \\
\hline & $2697.5-2763.5$ & $\begin{array}{l}\text { Beluga } \\
\text { (LFrigate) }\end{array}$ & Claystone & $\frac{0.20-0.54}{0.38(4)}$ & - & - & - & - \\
\hline & $2937.50-2948$ & $\begin{array}{l}\text { Jacaranda } \\
\text { (Elang) }\end{array}$ & Claystone & $\frac{0.37-0.49}{0.48(2)}$ & - & - & - & - \\
\hline & 3023 & Plover & Sandstone & 0.61 & 218.03 & 119.70 & 1.97 & 1.6 \\
\hline \multirow[t]{2}{*}{ Heron 1} & $3207-3499.20$ & $\begin{array}{l}\text { Echuca } \\
\text { Shoals }\end{array}$ & Claystone & $\frac{0.34-4.45}{2.02(32)}$ & $\frac{18.15-103.07}{50.31(25)}$ & $\frac{32.18-1097.06}{176.37(28)}$ & $\frac{0.25-7.82}{1.60(25)}$ & $\frac{0.04-1.78}{0.48(25)}$ \\
\hline & $3505.20-4186$ & $\begin{array}{c}\text { Petrel } \\
\text { (Frigate) }\end{array}$ & Shale & $\frac{0.56-26.40}{3.44(58)}$ & $\frac{3.57-233.46}{60.97(31)}$ & $\frac{4.69-822.38}{207.80(41)}$ & $\frac{0.43-23.90}{2.17(29)}$ & $\frac{0.07-1.70}{0.35(31)}$ \\
\hline \multirow[t]{3}{*}{$\begin{array}{c}\text { Evans } \\
\text { Shoal } 1\end{array}$} & $3462-3510$ & $\begin{array}{l}\text { Echuca } \\
\text { Shoals }\end{array}$ & Claystone & $\frac{0.90-2.29}{1.63(5)}$ & $\frac{18.48-50}{31.03(5)}$ & $\frac{10.04-365.56}{163.73(5)}$ & $\frac{0.47-1.07}{0.74(5)}$ & $\frac{0.08-3.13}{0.89(5)}$ \\
\hline & $3522-3540.98$ & $\begin{array}{c}\text { Cleia } \\
\text { (LFrigate) }\end{array}$ & Clayston & $\frac{0.81-1.40}{1.18(4)}$ & $\frac{30-57}{40.25(4)}$ & $\frac{23-1622}{508.75(4)}$ & $\frac{0.50-0.98}{0.80(4)}$ & $\frac{0.09-1.94}{0.84(4)}$ \\
\hline & $3645.20-3711.30$ & Plover & Claystone & $\frac{0.85-5.72}{2.86(6)}$ & $\frac{13.60-338}{167.43(6)}$ & $\frac{2.50-134.66}{61.54(6)}$ & $\frac{0.59-21.55}{6.32(6)}$ & $\frac{1.56-5.44}{3.09(6)}$ \\
\hline \multirow[t]{3}{*}{$\begin{array}{c}\text { Evans } \\
\text { Shoal } 2\end{array}$} & $3484.70-3497$ & $\begin{array}{l}\text { Echuca } \\
\text { Shoals }\end{array}$ & Claystone & $\frac{0.59-2.05}{1.38(5)}$ & $\frac{95-139}{118.40(5)}$ & $\frac{24-110}{64.80(5)}$ & $\frac{1.08-2.51}{2.02(5)}$ & $\frac{1.26-3.96}{2.22(6)}$ \\
\hline & $3497-3545$ & $\begin{array}{c}\text { Cleia } \\
\text { (LFrigate) }\end{array}$ & Claystone & $\frac{0.95-3.67}{1.92(10)}$ & $\frac{55-174}{99.10(10)}$ & $\frac{33-473}{108.20(10)}$ & $\frac{1.28-6.74}{2.38(10)}$ & $\frac{0.21-1.84}{1.35(10)}$ \\
\hline & $3563-3857$ & Plover & Claystone & $\frac{0.71-4.94}{1.85(4)}$ & $\frac{76-151}{100.75(4)}$ & $\frac{214-1283}{537.75(4)}$ & $\frac{0.88-8.15}{2.85(4)}$ & $\frac{0.06-0.29}{0.32(4)}$ \\
\hline
\end{tabular}

TOC is total organic carbon (wt\%). $(\mathrm{S} 1+\mathrm{S} 2)$ are the total amount of petroleum that might be generated from a rock. $\mathrm{S} 1$ is the free hydrocarbons (mg $\mathrm{HC} / \mathrm{g}$ rock). S2 is the hydrocarbon potential of source rock (mg HC/g rock). S2/S3 ratio can be used to determine what product is likely to be expelled from the rock during peak maturity. $\mathrm{S} 3$ is amount of oxygen-containing compounds generated during pyrolysis in $\mathrm{mg} \mathrm{CO}_{2} / \mathrm{g}$ rock. $\mathrm{HI}$ is the hydrogen index (mgHC/gTOC). OI is the oxygen index ( $\mathrm{mg} \mathrm{CO}_{2} / \mathrm{g} \mathrm{TOC}$ ). - is no data. Minimum value: Maximum value Average (number of samples). 
age of $2.86 \mathrm{wt} \%$ and from 0.59 to $21.55 \mathrm{mg} \mathrm{HC} / \mathrm{g}$ rock with an average of $6.32 \mathrm{mg} \mathrm{HC} / \mathrm{g}$ rock, indicating a fairto-very good source richness with poor-to-very good hydrocarbon generative potential. The Cleia (LFrigate) Formation source rock in the well Evans Shoal 2 comprises ten (10) TOC and S1 + S2 ranging from 0.95 to 3.67 wt $\%$ with an average of $1.92 \mathrm{wt} \%$ and from 1.28 to $6.74 \mathrm{mg} \mathrm{HC} / \mathrm{g}$ rock with an average of $2.38 \mathrm{mg} \mathrm{HC} / \mathrm{g}$ rock, likewise, the Plover Formation source rock in the same well contains four (4) TOC and S1 + S2 ranging from 0.71 to $4.94 \mathrm{wt} \%$ with an average of $1.85 \mathrm{wt} \%$ and from 0.88 to $8.15 \mathrm{mg} \mathrm{HC} / \mathrm{g}$ rock with an average of $2.85 \mathrm{mg}$ $\mathrm{HC} / \mathrm{g}$ rock, indicating a fair-to-very good organic richness with poor-to-good hydrocarbon generation potential (Figure 8(a)).

\subsection{Source Rock Type}

We assess the source rock type, based on the modified van Krevelen diagram of Hydrogen Index (HI) versus Oxygen Index (OI) (Figure 8(b)), and what we find on the liptinite (exinite), vitrinite, and inertinite, which are the three important maceral groups in coal and sedimentary rocks [22]. The HI and coal maceral data of Plover, Elang, Frigate Shale and Echuca Shoals formations source rocks in the Malita Graben is variable from one well to another (Table 2 and Table 3). The Tuatara (UFrigate) Formation source rock in the well Beluga 1 possesses two (2) HI ranging from 256.72 to $302.78 \mathrm{mg} \mathrm{HC} / \mathrm{g}$ TOC with an average of $279.75 \mathrm{mg} \mathrm{HC} / \mathrm{g}$ TOC showing kerogen type II \& III predominantly and two (2) S2/S3 ratios readings were recorded, which vary from 1.85 to 21.8, these values indicate mixed oil and gas prone. The Beluga (LFrigate) Formation source rock contains $33.30 \%$ exinite, $33.30 \%$ vitrinite, and $33.40 \%$ inertinite indicating kerogen type II \& III predominantly, and the Jacaranda (Elang) comprises $16.70 \%$ exinite, $66.70 \%$ vitrinite and $16.60 \%$ Inertinite showing kerogen type III predominantly, whereas the Plover Formation source rock gave a HI value of $218.03 \mathrm{mg} \mathrm{HC/g} \mathrm{TOC}$, this value indicates kerogen type II \& III and gas prone in reason of $\mathrm{S} 2 / \mathrm{S} 3<5$. The Echuca Shoals Formation in the well Heron 1, twenty five (25) HI readings were recorded, which range from 18.15 to $103.07 \mathrm{mg} \mathrm{HC} / \mathrm{g}$ TOC with an average of $50.31 \mathrm{mg} \mathrm{HC} / \mathrm{g} \mathrm{TOC}$, and the Petrel (Frigate) Formation source rock contains thirty one (31) HI va-

Table 3. Ro (\%) and Coal Maceral data for the Malita Graben source rock samples.

\begin{tabular}{|c|c|c|c|c|c|c|}
\hline Well & $\begin{array}{l}\text { Depth } \\
\text { (m) }\end{array}$ & Formation & $\operatorname{Ro}(\%)$ & $\begin{array}{c}\text { Exinite } \\
(\%)\end{array}$ & $\begin{array}{c}\text { Vitrinite } \\
(\%)\end{array}$ & $\begin{array}{c}\text { Inertinite } \\
(\%)\end{array}$ \\
\hline \multirow[t]{4}{*}{ Beluga 1} & 2515.50 & $\begin{array}{c}\text { Tuatara } \\
\text { (UFrigate) }\end{array}$ & $\frac{0.50-0.74}{0.59(25)}$ & 11.80 & 58.80 & 29.40 \\
\hline & 2697.50 & $\begin{array}{l}\text { Beluga } \\
\text { (LFrigate) }\end{array}$ & $\frac{0.55-0.70}{0.62(12)}$ & 33.30 & 33.30 & 33.40 \\
\hline & 2948 & $\begin{array}{l}\text { Jacaranda } \\
\text { (Elang) }\end{array}$ & $\frac{0.58-0.84}{0.67(25)}$ & 16.70 & 66.70 & 16.70 \\
\hline & 3023 & Plover & $\frac{0.46-0.84}{0.70(25)}$ & 16.70 & 33.30 & 50 \\
\hline \multirow[t]{2}{*}{ Heron 1} & $3247-3406$ & Echuca Shoals & $\frac{0.52-2.13}{1.32(21)}$ & 0 & 45 & 55 \\
\hline & $3506-4103.60$ & $\begin{array}{c}\text { Petrel } \\
\text { (Frigate) }\end{array}$ & $\frac{1.08-4.06}{2.07(100)}$ & 0 & 62.60 & 37.40 \\
\hline \multirow[t]{3}{*}{ Evans Shoal 1} & $3468.93-3509.95$ & Echuca Shoals & $\frac{1.14-1.54}{1.40(8)}$ & 0 & 3 & 97 \\
\hline & 3540.98 & Cleia & $\frac{1.32-1.49}{1.39(3)}$ & 0 & 2 & 98 \\
\hline & $3591-3711.30$ & Plover & $\frac{1.44-2.35}{2.02(42)}$ & 0 & 29.87 & 70.13 \\
\hline \multirow[t]{3}{*}{ Evans Shoal 2} & $3483-3497$ & Echuca Shoals & $\frac{0.41-0.61}{0.48(10)}$ & - & - & - \\
\hline & $3507-3521$ & Cleia (LFrigate) & $\frac{0.34-1.33}{0.99(49)}$ & - & - & - \\
\hline & $3563-3857$ & Plover & $\frac{0.68-2.11}{1.46(61)}$ & - & - & - \\
\hline
\end{tabular}

Ro (\%) is a vitrinate reflectance. - is no data. 
rying from 3.57 to $233.46 \mathrm{mg} \mathrm{HC} / \mathrm{g}$ TOC with an average of $60.97 \mathrm{mg} \mathrm{HC} / \mathrm{g}$ TOC, showing gas prone with type III kerogen predominantly. The Echuca Shoals Formation source rock in the well Evans Shoal 1 comprises five (5) HI, wich range from 18.48 to $50 \mathrm{mg} \mathrm{HC} / \mathrm{g}$ TOC with an average of $31.03 \mathrm{mg} \mathrm{HC} / \mathrm{g}$ TOC. Similarly, in the same well the Cleia (LFrigate) Formation source rock contains four (4) HI, varying from 30 to $57 \mathrm{mg} \mathrm{HC} / \mathrm{g}$ TOC with an average of $40.25 \mathrm{mg} \mathrm{HC} / \mathrm{g}$ TOC, indicating none to gas prone with type III kerogen predominantly, and Plover Formation source rock, six (6) HI readings were recorded, which vary from 13.60 to $338 \mathrm{mg} \mathrm{HC} / \mathrm{g}$ TOC with an average of $167.43 \mathrm{mg} \mathrm{HC} / \mathrm{g}$ TOC, showing kerogen type II \& III predominantly with gas prone, in reason of an average value of S2/S3 $<5$ (Table 2). The Echuca Shoals Formation in the well Evans Shoal 2 possesses five (5) HI, which range from 95 to $139 \mathrm{mg} \mathrm{HC} / \mathrm{g}$ TOC with an average of $118.40 \mathrm{mg} \mathrm{HC} / \mathrm{g} \mathrm{TOC}$, indicating gas prone with type III kerogen predominantly. Similarly, in the same well the Cleia (LFrigate) Formation source rock, ten (10) HI readings were recorded, which vary from 55 to $174 \mathrm{mg} \mathrm{HC} / \mathrm{g}$ TOC with an average of $99.10 \mathrm{mg} \mathrm{HC} / \mathrm{g}$ TOC, and Plover Formation source rock, four (4) HI readings were recorded, ranging from 76 to $151 \mathrm{mg} \mathrm{HC} / \mathrm{g}$ TOC with an average of $100.75 \mathrm{mg} \mathrm{HC} / \mathrm{g}$ TOC. Some source rocks from Echuca Shoals and Petrel (Frigate) formations in the well Heron 1, and Echuca Shoals, Cleia (LFrigate) and Plover formations in the Evans Shoal 1 well contain inertinite Type IV kerogen (Figure 8(b)) and (Table 2). These pyrolysis results and coal maceral data (Table 3) show that these formations are not expected to generate liquid hydrocarbons.

\subsection{Source Rock Maturity}

Vitrinate reflectance (Ro \%) value was used to assess the degree of thermal maturity attained by the examined source rocks in the study area (Figure 8(c)). The Tuatara (UFrigate) Formation source rock, twenty five (25) Ro readings were recorded, which range from $0.50 \%$ to $0.74 \%$, with an average of $0.59 \%$, the Beluga (LFrigate) Formation source rock, twelve (12) Ro readings were recorded, varying from $0.55 \%$ to $0.70 \%$, that have the mean value of $0.62 \%$, and the Jacaranda (Elang ) Formation source rock, twenty five (25) Ro readings were recorded, ranging from 0.58 to 0.84 , with an average of $0.67 \%$, these values indicate early to mid-mature oil window, corresponding to depth $2515.50 \mathrm{~m}, 2697.5 \mathrm{~m}$ and $2948 \mathrm{~m}$, respectively, whereas the Plover Formation source rock, twenty five (25) Ro readings were recorded, which vary from $0.46 \%$ to $0.84 \%$ that have the mean value of $0.70 \%$, indicating different maturity levels, varying from immature to mid-mature oil window with overall mean of mid-mature oil window, corresponding to depth $3023 \mathrm{~m}$. The Echuca Shoals Formation source rock in the well Heron 1, twenty one (21) Ro readings were recorded, which range from $0.56 \%$ to $2.13 \%$, that have the mean value of $1.32 \%$, showing different maturity levels, varying from early to post-mature with overall mean of late to post mature levels, corresponding to the depth of 3289 and $3390 \mathrm{~m}$, respectively, and the Petrel (Frigate) Formation source rock, one hundred (100) Ro readings were recorded, which vary from $1.08 \%$ to $4.06 \%$ with an average of $2.07 \%$, indicating late to post-mature with overall mean of post mature level, corresponding to the depth below 3561m, similarly, the Echuca Shoals Formation source rock in the well Evans Shoal 1 contains eight (8) Ro readings, ranging from $1.14 \%$ to $1.54 \%$ with an average of $1.40 \%$, corresponding the depth below $3469.93 \mathrm{~m}$. The Cleia (LFrigate) Formation source rock in the Evans Shoal 1 well has three (3) Ro, which vary from $1.32 \%$ to $1.49 \%$, with an average of $1.39 \%$, showing post mature level, corresponding to the depth of $3540.98 \mathrm{~m}$, likewise, the Plover Formation source rock, forty two (42) Ro readings were recorded, which range from $1.44 \%$ to $2.35 \%$, with an average of $2.02 \%$, corresponding to the depth below $3592.5 \mathrm{~m}$. The Echuca Shoals Formation source rock in the well Evans Shoal 2, ten (10) Ro readings were recorded, which vary from $0.41 \%$ to $0.61 \%$ that have the mean value of $0.48 \%$, indicating different maturity levels, varying from immature to early mature oil with overall mean of early mature oil window, corresponding to the depth of $3483 \mathrm{~m}$ and 3497 m, respectively, and in the same well the Cleia (LFrigate) Formation source rock, forty nine (49) Ro readings were recorded, ranging from $0.34 \%$ to $1.33 \%$ with an average of $0.99 \%$, showing different maturity levels, varying from immature to post mature with overall mean of mature level, corresponding to the depth below $3507 \mathrm{~m}$, whereas the Plover Formation source rock, sixty one (61) Ro readings were recorded, varying from $0.68 \%$ to $2.11 \%$ with an average of $1.46 \%$, these values indicate different maturity levels, varying from early mature to post-mature with overall mean of mature to post mature levels, corresponding to the depth of $3563 \mathrm{~m}$ and $3857 \mathrm{~m}$, respectively.

On the other hand, the interpretation of source rock maturation levels and hydrocarbon generation across in the study area was conducted using the Seismic Line N 11805 with present day heat flow value of $64 \mathrm{~mW} / \mathrm{m}^{2}$. The maturity is interpreted to have been initiated at a level of thermal maturity of $0.5 \%-0.7 \%$ Ro and con- 
cluded at a level of thermal maturity of $1.3 \%-2.0 \%$ Ro (Figure 9). The generation evolution history along this line can be described as follows: At $90 \mathrm{Ma}$, the Echuca Shoals Formation source rock was immature and at the base of Frigate Shale Formation entered early mature oil window throughout the study area, respectively, while at the base of Elang Formation source rock entered early mature oil window in the south margin and mid-mature oil window in the center and north margin of the study area, and at the base of Plover Formation source rock entered mid-mature in the south margin, whereas late mature oil window in the center and north margin of the study area (Figure 9(a)). At $65 \mathrm{Ma}$, the onset of the early mature oil occurred at the base of the Echuca Shoals Formation source rock throughout the study area. The early mature oil window entered at the base of the Frigate Shale Formation source rock in the south margin, and mid-mature oil window in the center and the north margin of the study area. The Elang and Plover formations source rocks entered mid-mature oil window in the south margin and late mature oil window in the center and the north margin of the study area (Figure 9(b)). At 23.3

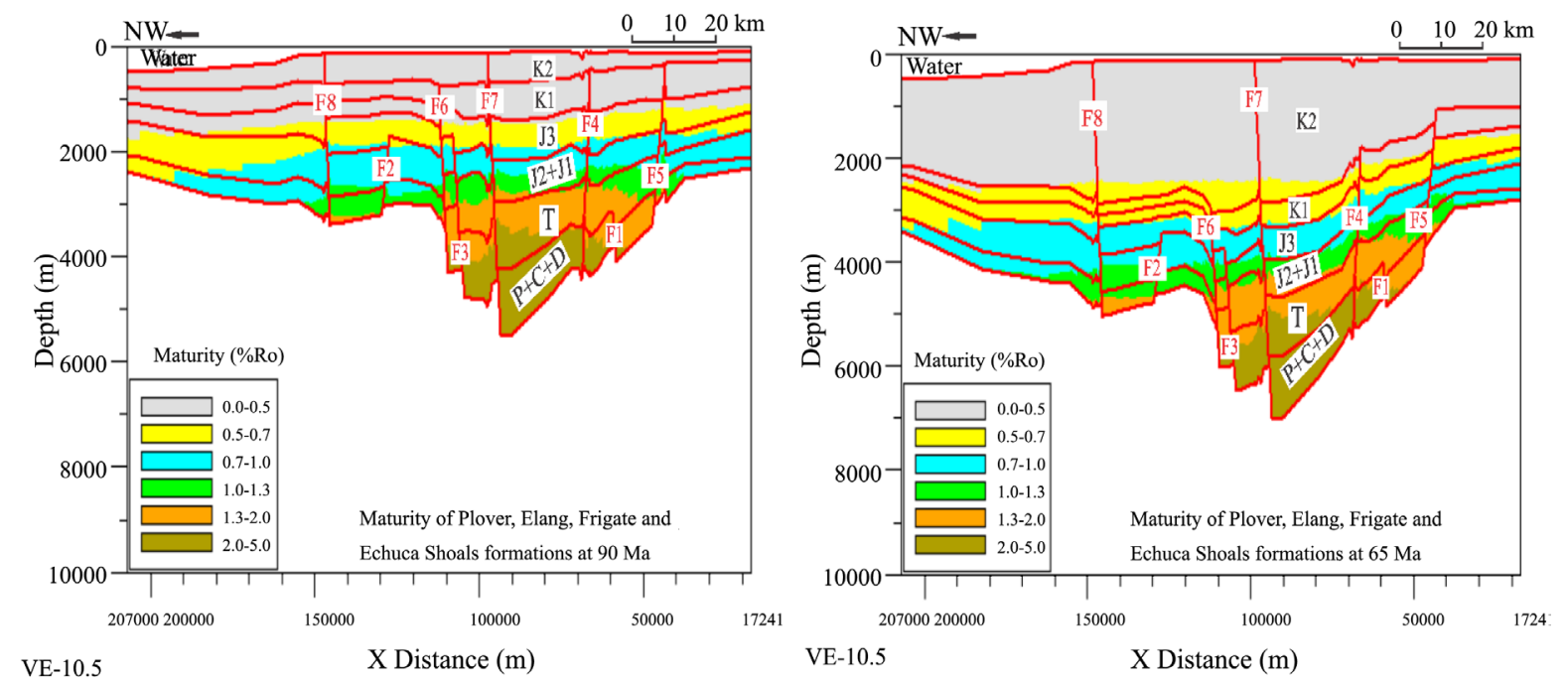

(a)

(b)

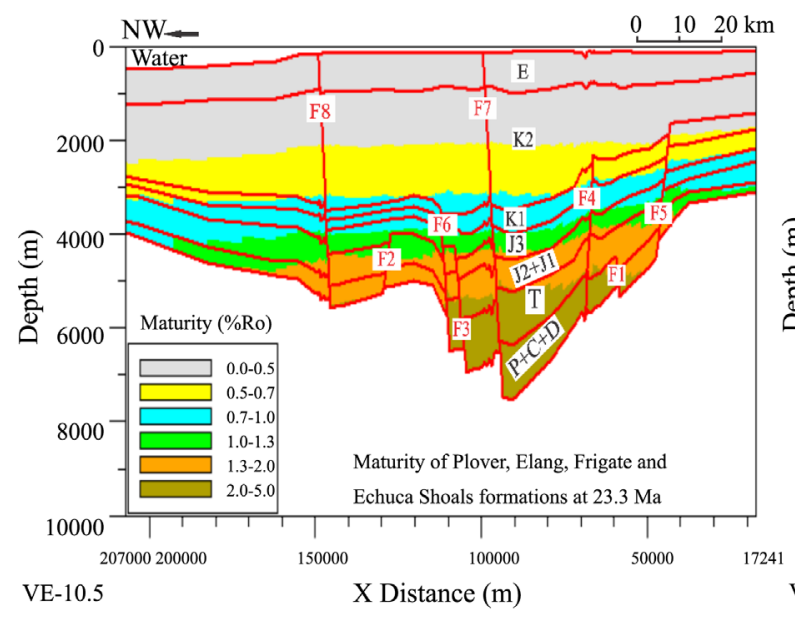

(c)

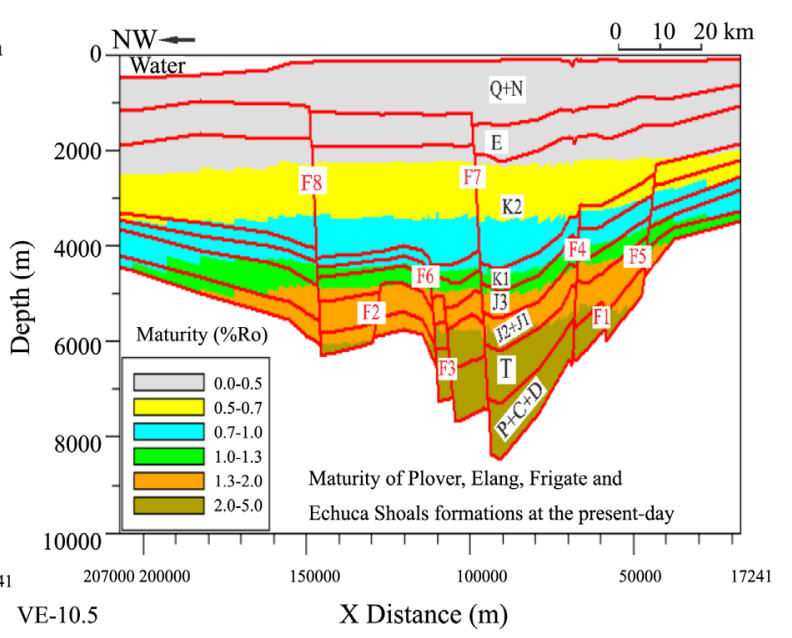

(d)

Figure 9. Schematic diagrams showing generation history of the Plover, Elang, Frigate and Echuca Shoals formations source rocks obtained from Seismic Line N11805. (a) source rock maturation at $90 \mathrm{Ma}$; (b) source rock maturation at $65 \mathrm{Ma}$; (c) source rock maturation at $23.3 \mathrm{Ma}$ and (d) source rock maturation at the present-day.The formation names are written in black capital alphabets as follows: $\mathrm{Q}+\mathrm{N}=$ Oliver, Barracouta and Alaria formations, $\mathrm{E}=$ Johnson, Hibernia and Cartier formations, $\mathrm{K}_{2}=$ Vee formation, $\mathrm{K}_{1}=$ Echuca Shoals, Darwin, Jamieson and Wangarlu formations, $\mathrm{J}_{3}=$ Elang and Frigate formations, $\mathrm{J}_{2}+\mathrm{J}_{1}=$ Plover Formation, $\mathrm{T}=\mathrm{Mt}$ Goodwin, Pollard and Malita formations and $\mathrm{P}+\mathrm{C}+\mathrm{D}=\mathrm{Hyland}$ Bay Formation, while the faults are segregated by red color of the letter F (F1 to F8). 
Ma, the Echuca Shoals Formation source rock entered early mature oil window in the south margin and mid-mature oil window in the center and the north margin of the study area. The Frigate Shale Formation source rock entered mid-mature oil window in the south margin and late mature oil window in the center and the north margin of the study area. The Elang and Plover formations source rocks entered mid-mature oil window in the south margin, late mature oil to wet gas window in the center and the north margin of the study area (Figure 9(c)). At the present-day, the Echuca Shoals Formation source rock entered early mature oil window in the south margin, and mid to late mature oil window in the center and the north margin of the study area. The Frigate Shale Formation source rock entered mid-mature oil window in the south margin and late mature oil to wet gas window in the center and the north margin of the study area. The Elang and Plover formations source rocks entered mid-mature oil window in the south margin and late mature oil to wet and dry gas window in the center and the north margin of the study area (Figure 9(d)). The modeling results are calibrated to the simulated Seismic Line N 11805 and to the measured vitrinite reflectance values for the wells of the study area (Figure 9 and Figure 10), and the correspondence between the simulated and the measured values is remarkably good, which indicates that the accuracy is relatively higher for both $1 \mathrm{D}$ and $2 \mathrm{D}$ modeling.

\subsection{Hydrocarbon Generation}

The level of maturation possibly reliant on temperature, time, and probably, pressure. The chemical laws of kinetics, as expressed in the Arrhenius equation, state that the rate of a chemical reaction is related to temperature and time. Reaction rate generally doubles for each $10^{\circ} \mathrm{C}$ increase. Thus, kerogen maturity is a function of temperature and time. The sedimentary organic matter is exposed to progressively higher subsurface temperatures, once it is buried in basins. The hydrocarbons under reducing conditions are yielded by thermal degradation of kerogen at temperatures of around $60^{\circ} \mathrm{C}$ and higher [23]. Hydrocarbon may therefore have been generated from old, cool source rocks as well as from young, hot ones and involves the transformation of kerogen in organic matter into liquid and gaseous phase. The wells Beluga 1, Heron 1, Evans Shoal 1, and Evans Shoal 2 were modeled to reconstruct burial, thermal and hydrocarbon generation histories of the study area. The present day thermal regime is obtained by calculating the transient heat flow in the wells Beluga $1\left(46.23 \mathrm{~mW} / \mathrm{m}^{2}\right)$, Heron $1\left(57.76 \mathrm{~mW} / \mathrm{m}^{2}\right)$, Evans Shoal $1\left(59.17 \mathrm{~mW} / \mathrm{m}^{2}\right)$, and Evans Shoal $2\left(61.99 \mathrm{~mW} / \mathrm{m}^{2}\right)$. The generation of hydrocarbons from the wells of the study area is demonstrated using BasinMod 1-D software, and the amount of hydrocarbon generation was calculated using Lawrence Livemore National Laboratory, taking into account Type II/III for Tuatara (UFrigate) Formation (mixed oil- and gas-prone) organic matter, and Type III BMOD-1 (gasprone) for all remaining formations. The default values of the kinetic parameters in the BasinMod 1-D software were used. The geochemical parameters such as total organic carbon (TOC) and hydrogen index (HI) were taken from the Table 2. In the well Beluga 1, the onset of early mature oil window of the Plover, Jacaranda (Elang), Beluga (LFrigate) and Tuatara (UFrigate) formations source rocks started in the Late Cretaceous at depth of about $1585 \mathrm{~m}, 1495 \mathrm{~m}, 1458 \mathrm{~m}$ and $1429 \mathrm{~m}$, respectively, and at temperature ranging between $85^{\circ} \mathrm{C}$ and $88^{\circ} \mathrm{C}$. In addition, the start of mid-mature oil window began in Early, Middle, Late Eocene, and Early Pliocene at the depth of $2504 \mathrm{~m}, 2393 \mathrm{~m}, 2334 \mathrm{~m}$ and $2356 \mathrm{~m}$, and at the temperature of $107^{\circ} \mathrm{C}, 105^{\circ} \mathrm{C}, 103^{\circ} \mathrm{C}$, and $102^{\circ} \mathrm{C}$, respectively (Figure 11(a)). The beginning of oil window of the Petrel (Frigate Shale) and Echuca Shoals formations source rock in the well Heron 1 began in Early and Middle Cretaceous at depth of $1151 \mathrm{~m}$ and $1120 \mathrm{~m}$ corresponding temperature of $85^{\circ} \mathrm{C}$ and $88^{\circ} \mathrm{C}$, respectively, and the wet gas window in the Late Cretaceous and Early Neogene at depth of about $3063 \mathrm{~m}$ and $3328 \mathrm{~m}$, and at temperature of $159^{\circ} \mathrm{C}$ and $155^{\circ} \mathrm{C}$, respectively (Figure 11(b)). The onset of oil window of Plover, Cleia (LFrigate) and Echuca Shoals formations source rocks in the well Evans Shoal 1 started in the Middle Cretaceous at depth of about 1615 m, 1598 m, and 1607 m, respectively and at temperature of $90^{\circ} \mathrm{C}$ and wet gas window during the Late Miocene, Late Pliocene and Pleistocene at $3398 \mathrm{~m}, 3459 \mathrm{~m}$ and $3468 \mathrm{~m}$ depth and $156^{\circ} \mathrm{C}, 160^{\circ} \mathrm{C}$ and $162^{\circ} \mathrm{C}$ temperature, respectively (Figure 11(c)). The start of oil window of the Plover Formation source rock in the well Evans Shoal 2 began in the Middle Cretaceous at the depth of about $1192 \mathrm{~m}$ and at temperature of $90^{\circ} \mathrm{C}$ and the wet gas window during Early Paleogene at $3191 \mathrm{~m}$ depth and $165^{\circ} \mathrm{C}$ temperature, and the onset of oil window of the Cleia (LFrigate) and Echuca Shoals formations source rocks, in the same well, commenced in the Late Cretaceous at the depth of about $1045 \mathrm{~m}$ and $1027 \mathrm{~m}$ and $90^{\circ} \mathrm{C}$ temperature, respectively, and the wet gas window during Middle and Late Paleogene at the depth of about $2897 \mathrm{~m}$ and $2905 \mathrm{~m}$, and at temperature $155^{\circ} \mathrm{C}$, respectively (Figure $11(\mathrm{~d})$ ). The amount of oil generated from the Plover and Tuatara (UFrigate) formations in the well Beluga 1 are 15.10 and $21.16 \mathrm{mg} / \mathrm{g}$ TOC and gas are 33.36 and $13.28 \mathrm{mg} / \mathrm{g}$ TOC, respectively (Figure 12(a)), whereas the peak genera 

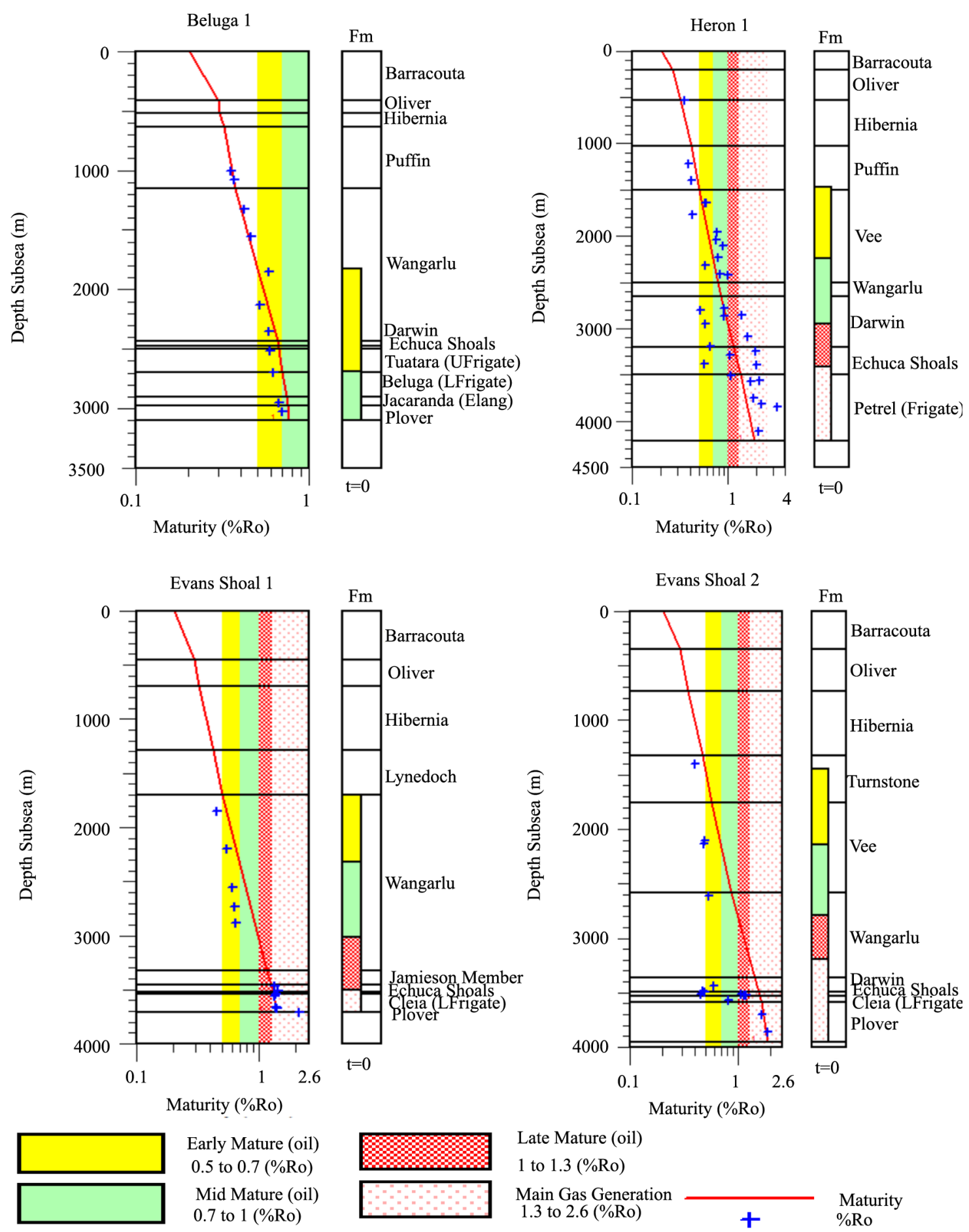

Figure 10. Thermal maturity history identifying the fitness of the modelled and measured \% Ro for fourwellsin the Malita Graben.

tion for Plover Formation was at Late Cretaceous and for Tuatara (UFrigate) is at present-day (Figure 12(b)). The amount of gas generated from the Petrel (Frigate Shale) and Echuca Shoals formations in the well Heron 1 are 36.29 and $26.77 \mathrm{mg} / \mathrm{g} \mathrm{TOC}$, and oil are 15.30 and $11.95 \mathrm{mg} / \mathrm{g}$ TOC, respectively (Figure 13(a)), while their peak generation was recognized during the Late Cretaceous (Figure 13(b)). The amount of gas generated from the Plover, Cleia (LFrigate) and Echuca Shoals formations formations in the well Evans Shoal 1 are 66.98, 18.89 


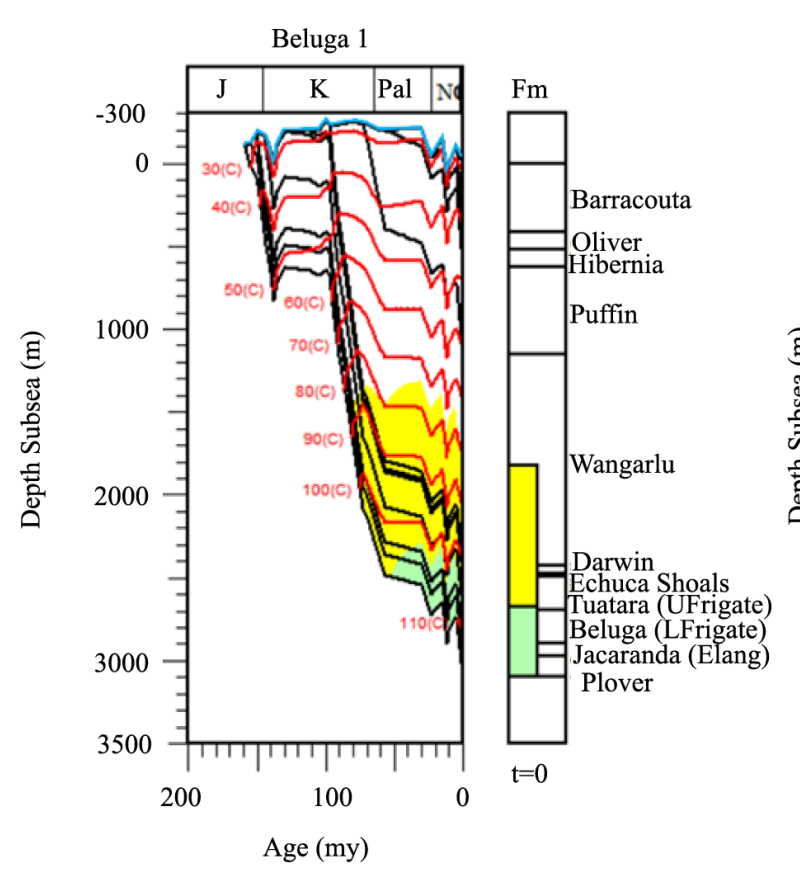

(a)

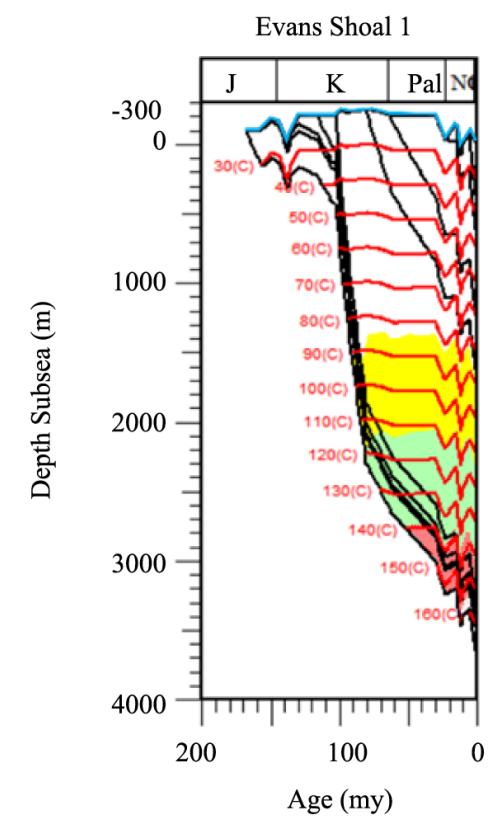

(c)

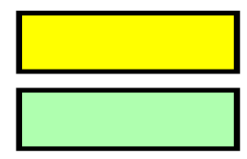

Early Mature (oil) 0.5 to 0.7 (\%Ro) Mid Mature (oil) 0.7 to 1 (\%Ro)

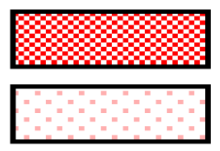

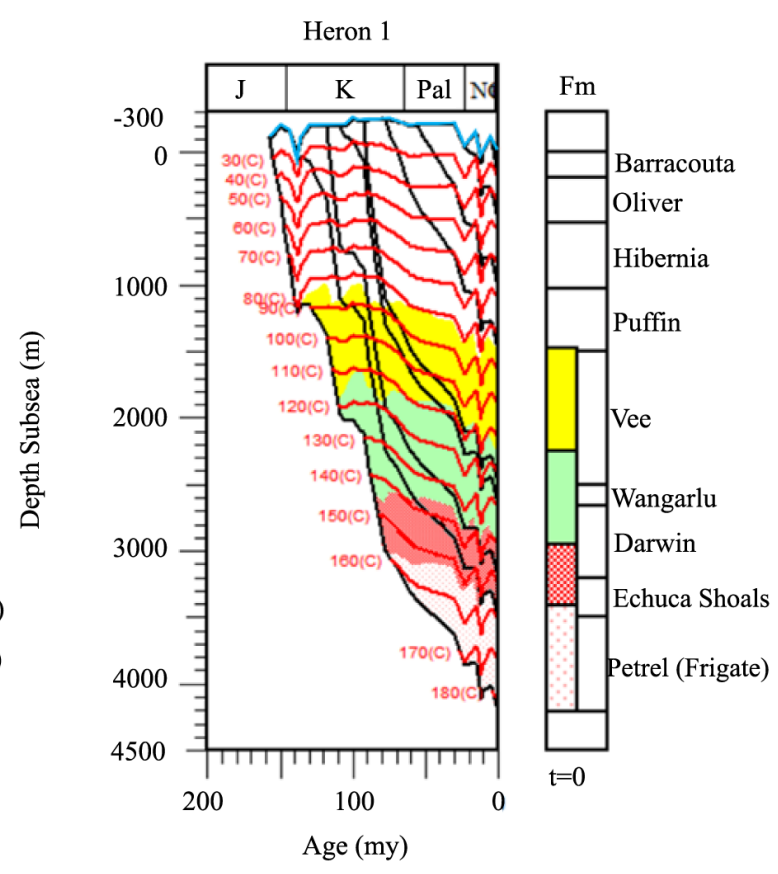

(b)

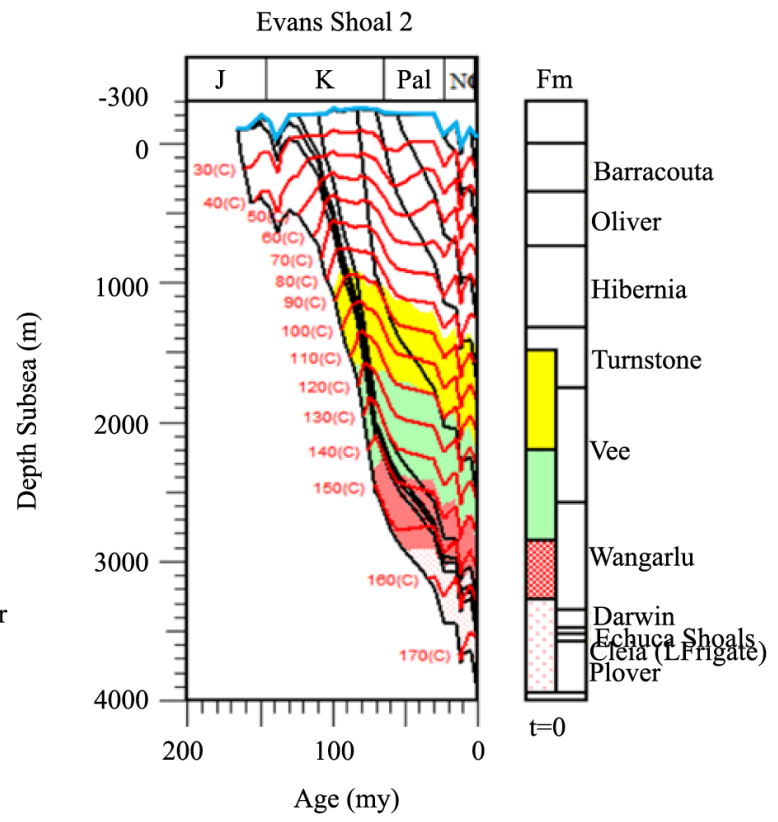

(d)

Late Mature (oil)

1 to $1.3(\%$ Ro)

Main Gas Generation

1.3 to 2.6 (\%Ro)

Sea level

Figure 11. Modelled burial history of the wells (a) Beluga 1; (b) Heron 1; (c) Evans Shoal 1 and (d) Evans Shoal 2 in the Malita Graben. where: $\mathrm{J}=$ Jurassic, $\mathrm{K}=$ Cretaceous, $\mathrm{Pal}=$ Paleogene, $\mathrm{N}=$ Neogene, $\mathrm{Q}=$ Quaternary.

and $14.29 \mathrm{mg} / \mathrm{g}$ TOC and oil are 29.55, 8.22 and $6.13 \mathrm{mg} / \mathrm{g}$ TOC, respectively (Figure 14(a)), while their peak generation was recognized during Early Paleogene (Figure 14(b)). The amount of gas generated from the Plov- 


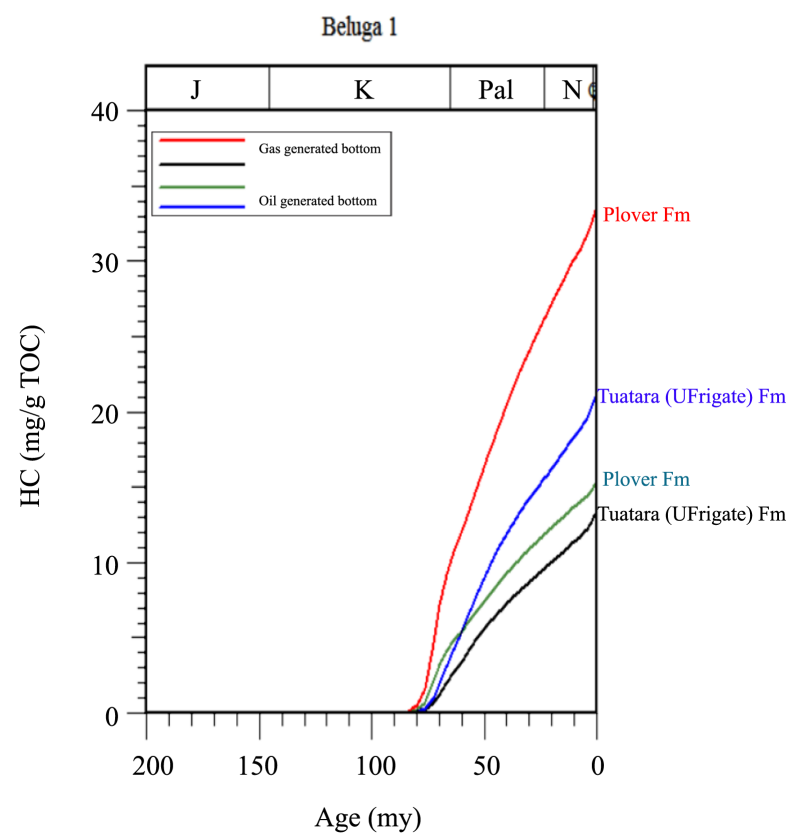

(a)

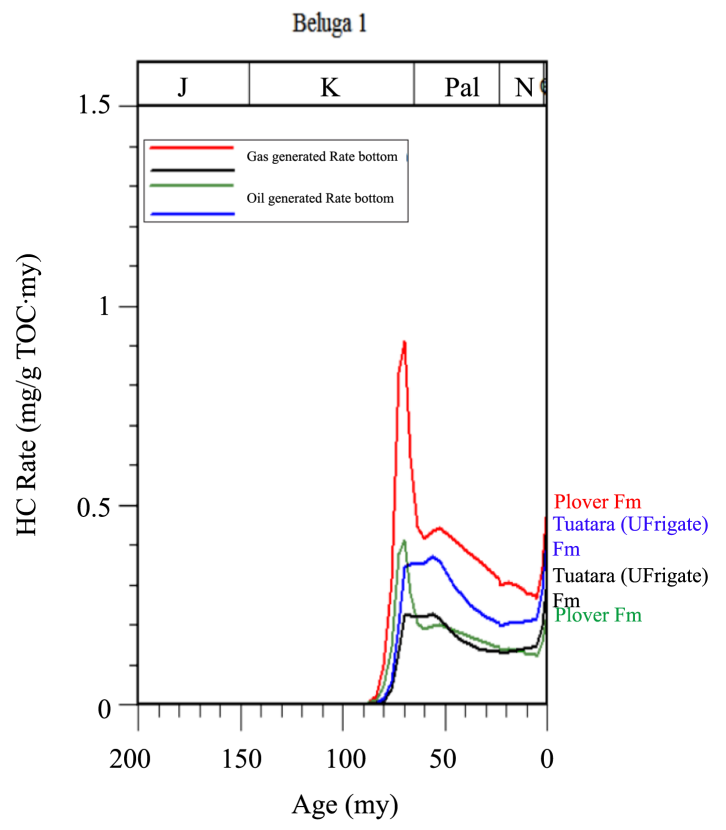

(b)

Figure 12. Modeling results of hydrocarbon generation history in the well Beluga 1. (a) Amount of hydrocarbon generation; (b) Rate of hydrocarbon showing the peak generation at Late Cretaceous for the Plover Formation and present-day for Tuatara (UFrigate) Formation.

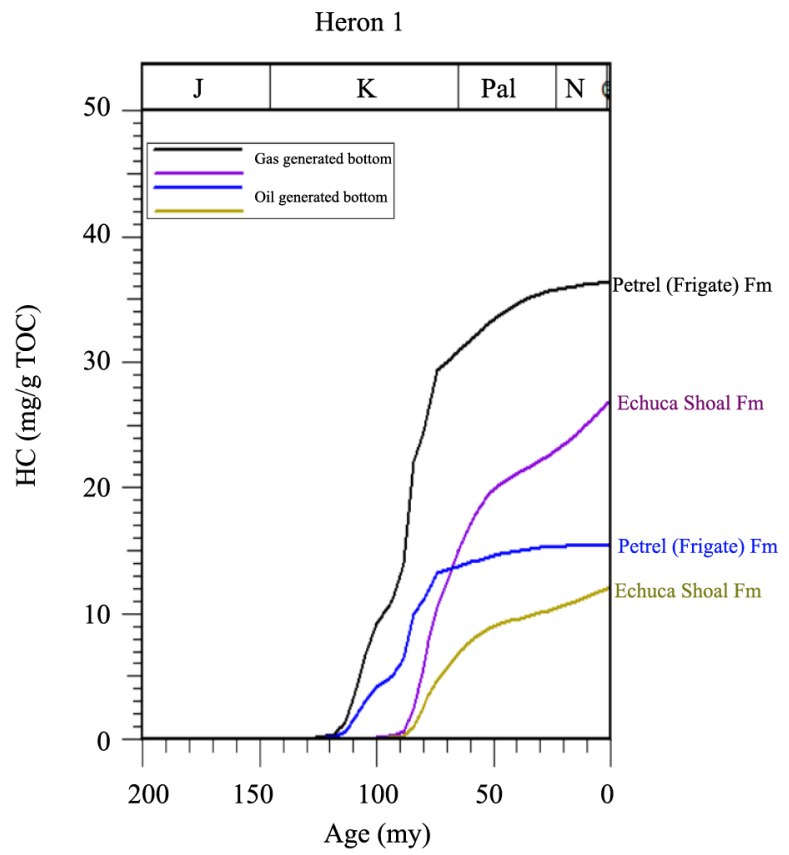

(a)

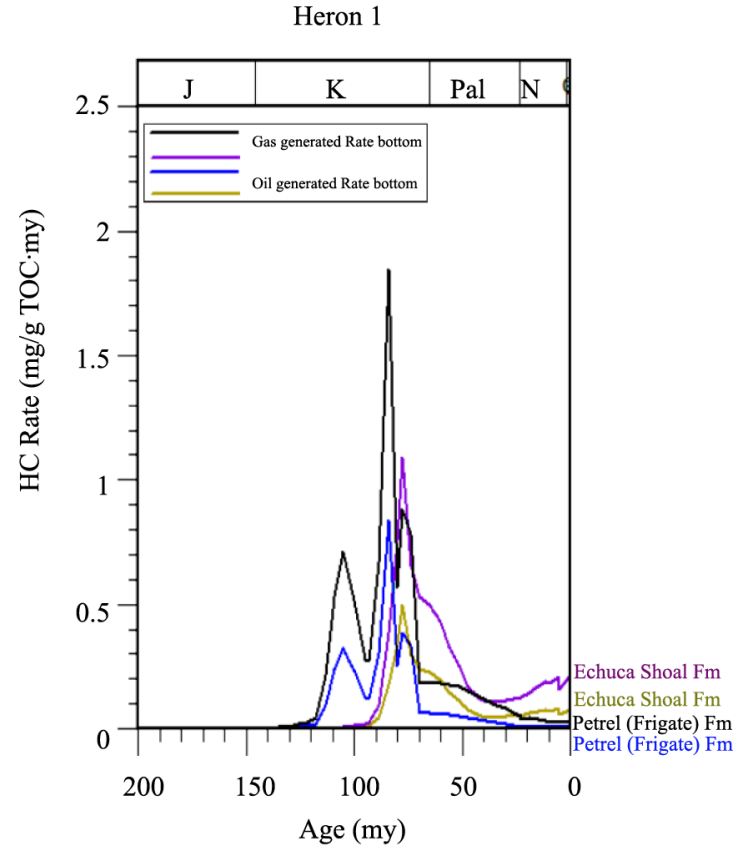

(b)

Figure 13. Modeling results of hydrocarbon generation history in the well Heron 1. (a) Amount of hydrocarbon generation; (b) Rate of hydrocarbon showing the peak generation at the Late Cretaceous for the Petrel (Frigate) and Echuca Shoals formations.

er, Cleia (LFrigate) and Echuca Shoalsformations in the well Evans Shoal 2 are 63.84, 57.34 and $65.73 \mathrm{mg} / \mathrm{g}$ TOC and oil are 25.16, 23.91, and $27.88 \mathrm{mg} / \mathrm{g}$ TOC, respectively (Figure 15(a)), whereas the peak generation of 


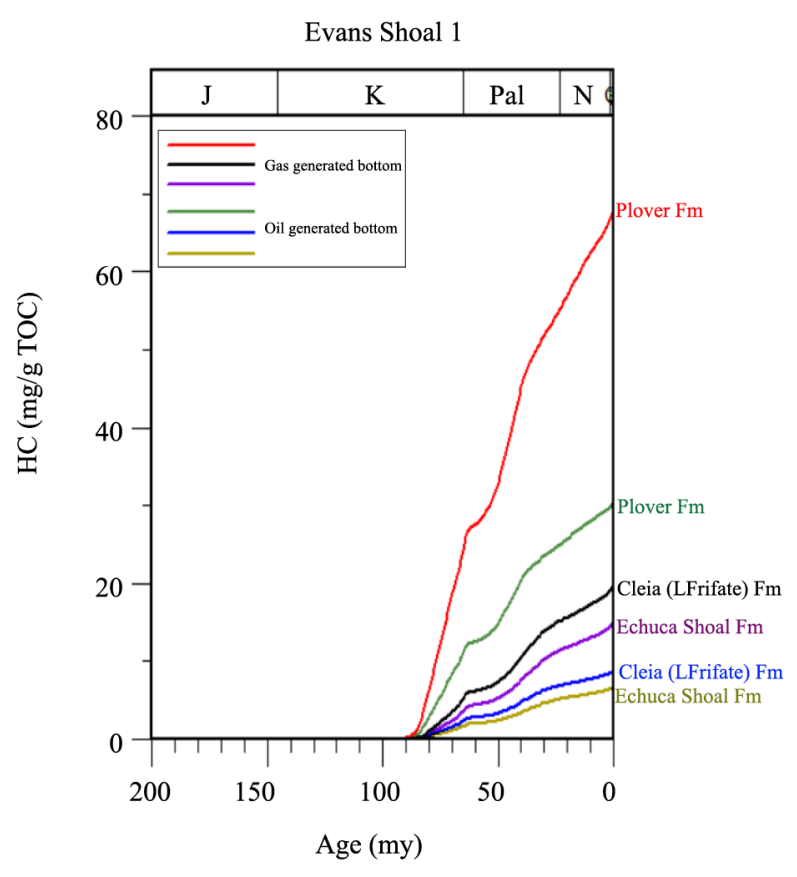

(a)

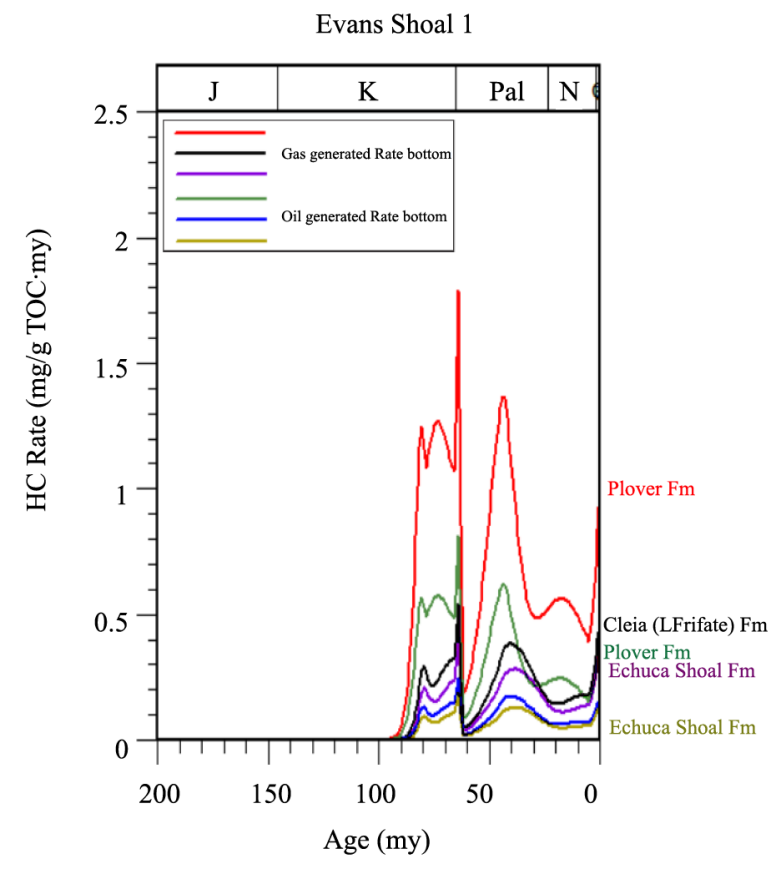

(b)

Figure 14. Modeling results of hydrocarbon generation history in the well Evans Shoall. (a) Amount of hydrocarbon generation; (b) Rate of hydrocarbon showing the peak generation at Early Paleogene for the Plover, Cleia (LFrigate) and Echuca Shoals formations.

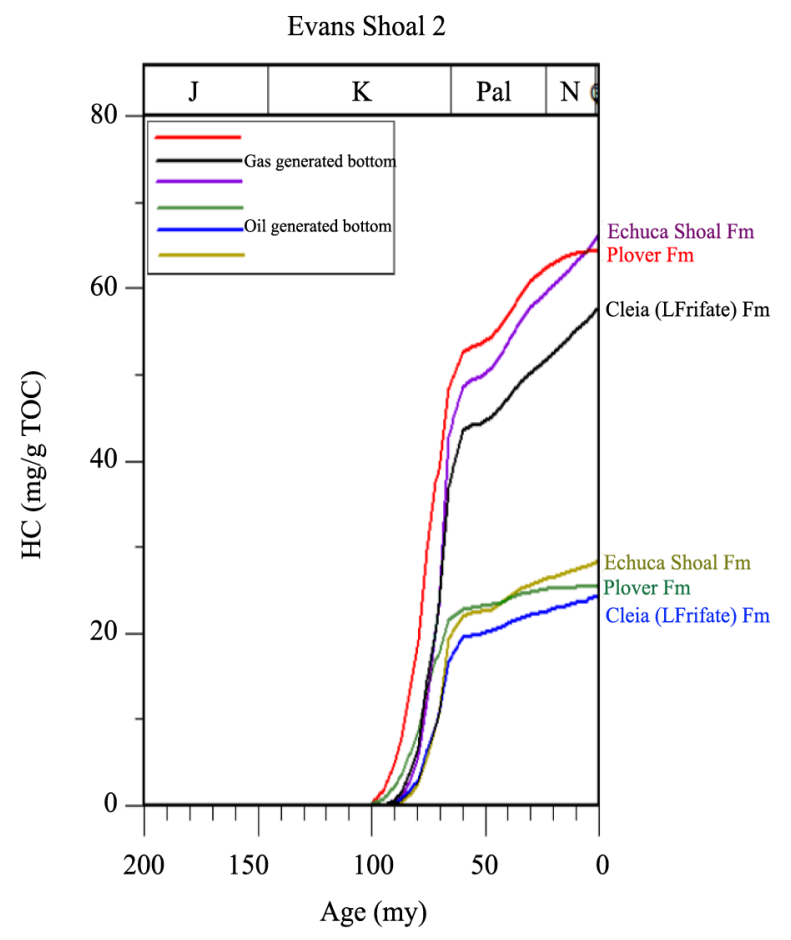

(a)

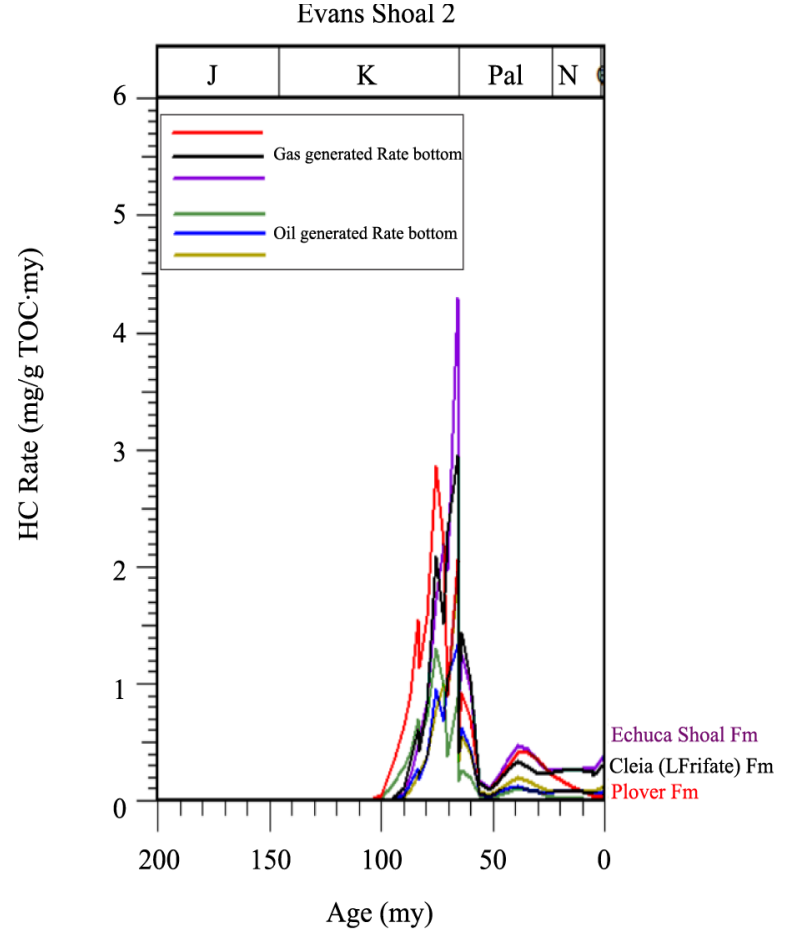

(b)

Figure 15. Modeling results of hydrocarbon generation history in the well Evans Shoal 2. (a) Amount of hydrocarbon generation; (b) Rate of hydrocarbon showing the peak generation at the Late Cretaceous for the Plover Formation and at Early Paleogene for Cleia (LFrigate) and Echuca Shoals formations. 
the Plover Formation was recognized during the Late Cretaceous and Cleia (LFrigate) and Echuca Shoals formations during the Early Paleogene (Figure 15(b)).

\section{Conclusions}

The data from wells Beluga 1, Heron 1, Evans Shoal 1, Evans Shoal 2, and Seismic Line N 11805 with BasinMod 1-D and 2-D techniques are used to investigate the burial, thermal, maturity, generation histories and potential of hydrocarbon generated from the Plover, Elang, Frigate Shale (Cleia, Flamingo), and Echuca Shoals formations source rocks in the Malita Graben. The geothermal gradient values range from $3.05^{\circ} \mathrm{C} / 100 \mathrm{~m}$ to $4.05^{\circ} \mathrm{C} / 100 \mathrm{~m}$ and the present-day heat flow values change from 46.23 to $61.99 \mathrm{~mW} / \mathrm{m}^{2}$. The highest geothermal gradient and present-day heat flow values occurred on a terrace north of the Malita Graben. These most likely indicate that hot fluids are currently variably migrating into this structure. The lower geothermal gradient and heat flow values have been modeled in the southeast sites in the well Beluga 1. The northern Bonaparte Basin experienced several deformation phases including lithospheric thinning. Hence, the heat flow is expected to vary over the geological history of the basin. The higher paleo-heat flow values changing from 83.54 to $112.01 \mathrm{~mW} / \mathrm{m}^{2}$ with an average of $101.71 \mathrm{~mW} / \mathrm{m}^{2}$ during Jurassic rift event (syn-rift) were sufficient for source rocks maturation and hydrocarbon generation throughout Cretaceous post-breakup sequence (post-rift) in the study area. The Jacaranda (Elang) Formation source rock showing kerogen type III and Beluga (Lower Frigate Shale) Formation source rock with kerogen type II \& III are poor source richness, and Plover Formation source rock showing gasprone with kerogen type III and Tuatara (Upper Frigate Shale) Formation source rock mixed oil-and gas-prone with kerogen type II \& III are a fair-to-good organic richness with poor-to-fair potential generative hydrocarbons in the well Beluga 1 and are currently early to mid-mature oil window. An early to post mature and a poorto-very good source richness with poor-to-very good potential hydrocarbon generation of Petrel (Frigate Shale) and Echuca Shoals formations source rocks in the well Heron 1 show gas-prone with type III kerogen predominantly. The post-mature Cleia and Echuca Shoals formations source rocks in the well Evans Shoal 1 and an early mature oil window Echuca Shoals Formation source rock in the well Evans Shoal 2 characterized by type III kerogen predominantly showing gas-prone are a fair-to-very good source richness with poor potential for hydrocarbons generation. However, the post-mature of the Plover Formation in the Evans Shoal 1 well, Plover and Cleia (Lower Frigate Shale) formations in the Evans Shoal 2 well source rocks are a fair-to-very good organic richness with poor-to-very good potential for hydrocarbons generation showing gas-prone with type II \& III kerogen predominantly, and have reached in the wet gas generation stages at the present day in the study area. It indicates a future exploration hydrocarbon fields at the center and northern flanks of the Malita Graben throughout Early Cretaceous Darwin Formation to Early-Middle Jurassic Plover Formation.

\section{Acknowledgements}

The authors would like to acknowledge the Department of Oil and Gas Exploration, Faculty of Earth Resources, China University of Geosciences (Wuhan), for the financial support and provision of all the required data for the research.

\section{References}

[1] Preston, J.C. and Edwards, D.S. (2000) The Petroleum Geochemistry of Oils and Source Rocks from the Northern Bonaparte Basin, Offshore Northern Australia. Australian Petroleum Production Exploration Association Journal, 1, $257-$ 282.

[2] Abbassi, S., George, S.C., Edwards, D.S., di Primio, R., Horsfield, B. and Volk, H. (2015) On the Filling and Leakage of Petroleum from Traps in the Laminaria High Region of the Northern Bonaparte Basin, Australia. Marine and Petroleum Geology, 59, 91-113. http://dx.doi.org/10.1016/j.marpetgeo.2014.07.030

[3] Ambrose, G.J. (2004) The Ongoing Search for Oil in the Timor Sea, Australia. In: Ellis, G.K., Baillie, P.W. and Munson, T.J., Eds., Timor Sea Petroleum Geoscience, Proceedings of the Timor Sea Symposium, Darwin, Northern Territory, 19-20 June 2003, 2-22. Northern Territory Geological Survey, Special Publication 1.

[4] Edwards, D.S., Boreham, C.J., Zumberge, J.E., Hope, J.M., Kennard, J.M. and Summons, R.E. (2006) Hydrocarbon Families of the Australian North West Shelf: A Regional Synthesis of the Bulk, Molecular and Isotopic Composition of Oils and Gases. AAPG International Conference and Exhibition, Perth.

[5] Geary, G. (2008) Farmin Opportunity Presentation NT/P68 \& Amp; WA-361-P. MEO Australia Limited, PESA Far- 
min Seminar.

[6] Labutis, V.R., Ruddock, A.D. and Calcraft, A.P. (1998) Stratigraphy of the Southern Sahul Platform. APPEA Journal, 1, 115-136.

[7] Shuster, M.W., Eaton, S., Wakefield, L.L. and Kloosterman, H.J. (1998) Neogene Tectonics, Greater Timor Sea, Offshore Australia: Implications for Trap Risk. The APPEA Journal, 1, 351-379.

[8] Cadman, S.J. and Temple, P.R. (2004) Bonaparte Basin, NT, WA, AC \& JPDA, Australian Petroleum Accumulations Report 5. 2nd Edition, Geoscience Australia, Canberra.

[9] Pickard, G.L. (1964) Descriptive Physical Oceanography: An Introduction. Macmillan, New York.

[10] Hardenbol, J., Thierry, J., Farley, M.B., Jacquin, T., de Graciansky, P.C. and Vail, P. (1998) Mesozoic and Cenozoic Sequence Chronostratigraphic Framework of European Basins. In: Graciansky, P.C., et al., Eds., Mesozoic and Cenozoic Sequence Stratigraphy of European Basins, SEPM Special Publication 60, Tulsa, Charts 1-8, 3-13.

[11] Haq, B.U. and Al-Qahtani, A.M. (2005) Phanerozoic Cycles of Sea-Level Change on the Arabian Platform. GeoArabia, 2, 127-160.

[12] Haq, B.U. and S.R. Shutter. (2008) A Chronology of Paleozoic Sea-Level Changes. Science, 322, 64-68. http://dx.doi.org/10.1126/science.1161648

[13] Sclater, J.G. and Christie, P.A.F. (1980) Continental Stretching: An Explanation of the Post-Mid-Cretaceous Subsidence of the Central North Sea Basin. Journal of Geophysical Research, 85, 3711-3739. http://dx.doi.org/10.1029/JB085iB07p03711

[14] Steckler, M.S. and Watts, A.B. (1978) Subsidence of the Atlantic Type Continental Margin off New York. Earth and Planetary Science Letters, 41, 1-13. http://dx.doi.org/10.1016/0012-821X(78)90036-5

[15] Jarvis, G.T. and Mckenzie D.P. (1980) Sedimentary Basin Formation with Finite Extension Rates. Earth and Planetary Science Letters, 48, 42-52. http://dx.doi.org/10.1016/0012-821X(80)90168-5

[16] Allen, P.A. and Allen, J.R. (2005) Basin Analysis Principles \& Applications. Blackwell Science, Oxford.

[17] Van Krevelen, D.W. (1961) Coal. Typology-Chemistry-Physics-Constitution. Elsevier, Amsterdam.

[18] Peters, K.E., Walters, C.C. and Moldowan, J.M. (2005) The Biomarker Guide, Volume 1 and 2. Second Edition, Cambridge University Press, Cambridge.

[19] Lerche, I., Yarzab, R. F. and Kendall, C.G.S. (1984) Determination of Paleo-Heat Flux from Vitrinite Reflectance Data. Bulletin of the American Association of Petroleum Geologists, 68, 1704-1717.

[20] Ameed, R.K.G., Arthur, J.M. and Robert, P.I. (2005) Modelling Petroleum Generation in the Paleozoic of the Carnarvon Basin, Western Australia: Implications for Prospectivity. AAPG Bulletin, 89, 27-40. http://dx.doi.org/10.1306/08150403134

[21] Peters, K.E. and Cassa, M.R. (1994) Applied Source-Rock Geochemistry. In: Magoon, L.B. and Dow, W.G., Eds., The Petroleum System. From Source to Trap, American Association of Petroleum Geologists, Tulsa, 93-120

[22] Suárez-Ruiz, I. and Crelling, J.C. (2008) Applied Coal Petrology. The Role of Petrology in Coal Utilization. Elsevier, Amsterdam.

[23] Hunt, J.M. (1996) Petroleum Geochemistry and Geology. 2nd Edition, W.H. Freeman, New York. 